\title{
Saving Behavior and Portfolio Choice After Retirement
}

\author{
Raun van Ooijen ${ }^{1,2}$ Rob Alessie ${ }^{1,2}$. \\ Adriaan Kalwij ${ }^{2,3}$
}

(C) The Author(s) 2015. This article is published with open access at Springerlink.com

\begin{abstract}
This paper reviews the literature on saving behavior and portfolio choice after retirement and provides a descriptive analysis of this behavior by Dutch elderly households. Studying saving behavior in the Netherlands is informative because of the very different institutional background compared to the US, for which most of the empirical evidence is. In the Netherlands, the generous pension system and almost complete coverage of the public health- and long-term care insurance system makes precautionary saving less necessary. Using detailed administrative data, we present evidence on the extent to which the financial resources of retirees are affected by shocks such as the decease of a spouse or deteriorating health-similar to recent empirical studies by Poterba et al. (Explorations in the economics of aging. University of Chicago
\end{abstract}

We are grateful to Mariacristina De Nardi, Gerard van den Berg, Christopher Carroll, Peter van Santen, Mark van Duijn, Jan Rouwendal, and seminar participants at the 2013 European Society of Population Economics Conference, Healthwise Kickoff Conference, Groningen, the 2013 Netspar International Pension Workshop, Netspar Conference on "Retirement and the Financial Position of the Elderly", the 2013 NHH-UiO Workshop for Economic Dynamics, Oslo and the University of Mannheim for helpful comments and suggestions.

$凶 \quad$ Rob Alessie

r.j.m.alessie@rug.nl

Raun van Ooijen

r.van.ooijen@rug.nl

Adriaan Kalwij

a.s.kalwij@uu.nl

1 Department of Economics, Econometrics and Finance, University of Groningen, 9700 AV Groningen, The Netherlands

2 Netspar, Groningen, The Netherlands

3 Utrecht University School of Economics, Utrecht University, Utrecht, The Netherlands 
Press, Chicago, pp 23-69, 2011; Investigations in the economics of aging. University of Chicago Press, Chicago, pp 21-69, 2012; Discoveries in the economics of aging. University of Chicago Press, Chicago, pp 159-186, 2014) for the US. Moreover, we examine the extent to which retirees who do not experience any shocks are able to keep positive wealth at their disposal and sustain their consumption level during retirement. Our results show that the death of the spouse results in a significant reduction of household wealth compared to surviving couples_-which is also found in the USwhile health shocks result in higher household savings in old-age due to the almost complete coverage of health care expenditures. Although retirees in the Netherlands face limited uncertainty about health expenditures, our analysis shows that the elderly, on average, keep large amounts of assets even at a very old age. Our findings suggest that (1) the generous pension benefits are protective of household wealth, (2) illiquid housing wealth constrains the decumulation of household wealth, (3) bequests and transfers after the death of the first spouse are important.

\section{Keywords Savings $\cdot$ Portfolio choice $\cdot$ Elderly}

JEL Classification $\quad \mathrm{J} 14 \cdot \mathrm{J} 26 \cdot \mathrm{D} 14 \cdot \mathrm{D} 31$

\section{Introduction}

As the babyboomer generation has reached the statutory retirement age, public expenditures on state pensions and long-term care will increase progressively in the coming decades in the Netherlands, as in other West-European countries and the United States. This is due to the aging of the population and increasing life expectancy. In addition, the financial crisis has shown that the pension system is vulnerable to shocks in financial markets. Many Dutch pension funds have had difficulties achieving full indexation of accrued pension rights against inflation, and several pension funds have even had to cut pension benefits.

As a result, substantial reforms of the pension and long-term care insurance system have been announced or already have been implemented in order to ensure sustainability of public finances and the pension system. The pension reforms include a phased increase of the statutory retirement age to 67 years in 2024. After that, the retirement age will be linked to the rise in the life expectancy. In addition, there will be a substantial reduction in the tax-favored pension accrual rate and limited inflation-linking. This will further reduce pension benefits. Changes in the long-term care insurance system imply that only the major disabilities for which self-funding is impossible will be covered. The remainder of care has to be paid out-of-pocket, such as health expenses on social support and accommodation costs for persons who stay in a nursing home.

The proposed reforms thus demand that individuals take more responsibility to financially prepare for retirement and secure part of their resources for uncertain health expenses. From a policy perspective, it is therefore important to know the extent of financial resources available to current retirees; whether these resources are sufficient to support them in case of financial shocks such as adverse health events, widowhood or nursing home entry; and whether they will adjust their savings in response to 
the proposed policy reforms. Answering these questions requires a thorough understanding of saving decisions in retirement. Does a reduction in the provision of health insurance by the Government increase precautionary savings? Will a reduction in pension benefits increase the importance of private wealth holdings and result in smaller bequests? Will the elderly invest more in the stock market to have a larger return on their savings or will they reduce their holdings in risky stocks because of increased health expenditure risk?

This paper reviews the theoretical and empirical literature about saving behavior and portfolio choice after retirement. Detailed administrative data are then used to provide descriptive evidence about saving behavior and portfolio choice of the elderly in the Netherlands. The linked administrative records contain information on assets, liabilities, pension income, health status and demographics for the period 2005-2010. To the best of our knowledge, we are the first to use these administrative records to investigate this topic. The advantage of our data is that we measure assets and also health status with a higher quality than survey data. In addition, rich and poor households are not underrepresented. Data quality problems such as measurement error, sample attrition and item-nonresponse are important concerns for longitudinal analysis such as saving behavior (Venti 2011; Card et al. 2010).

It is informative to study saving behavior in the Netherlands because of the very different institutional background compared to the US. The almost complete coverage of the health- and long-term care insurance system makes precautionary saving less necessary. Also in the future, saving for long-term care expenses will probably be limited, since the eligibility for public long-term care will depend on the level of wealth. This requires persons to first run down their assets to become eligible for long-term care and penalizes those who find it important to save for this purpose.

The outline is as follows. Section 2 surveys theoretical and empirical work on saving- and portfolio behavior after retirement. Section 3 describes the administrative data sources. Section 4 provides a descriptive analysis of the wealth distribution and portfolio choice of the Dutch elderly. In addition, we indicate how wealth holdings evolve during old-age. Section 5 examines how assets are affected by the death of a spouse. Section 6 investigates the relationship between health status and the savings and portfolio choices of the elderly. Section 7 investigates the trajectory of wealth in the last years of life. The final section draws conclusions and provides implications for public policy to facility the use of private savings in retirement.

\section{Theory on Saving Behavior and Portfolio Choice After Retirement}

A simple version of the life-cycle theory of consumption (Modigliani and Brumberg 1954) without uncertainty and a bequest motive predicts that people accumulate wealth during working life and draw down their savings after retirement to support consumption when income is low. This predicted pattern - that wealth should eventually decline with age-is, however, not found by many empirical studies for several Western countries. According to recent empirical research by Love et al. (2009) and Poterba et al. (2011), median wealth holdings rise in retirement for both single-person households and two-person households - although the rise in wealth tends to be limited among 
the oldest cohort of single elderly. Their data come from the 1992 to 2006 US Health and Retirement Survey (HRS). These findings hold for different measures of wealth including financial assets, housing equity and "annualized comprehensive wealth", which also includes the expected net present value of pension wealth as well as social security wealth. Similar findings are found in countries with very different institutional settings such as the Netherlands (Alessie et al. 1999) and Germany (Börsch-Supan 1992).

These results are different from earlier studies that report high rates of dissaving in the 1970s (e.g. Hurd 1987; Diamond and Hausman 1984). A possible explanation for the difference is that these studies use a cohort of relatively young retired households who might use their savings to finance involuntary early retirement. Another explanation are the relative high capital gains over the 1992-2006 period due to the rise in housing prices and stock prices. This may have caused the observed change in savings to differ from the planned change in savings. French et al. (2007) show that wealth holdings would have declined over the same period if the rates of return on assets were equal to historical rates. Hence, it is important to account for capital gains in the analysis of saving behavior.

All of the studies mentioned above also reported considerable heterogeneity in saving behavior. In particular, richer households and households with a higher level of education tend to save more (see also Hubbard et al. 1995; Dynan et al. 2004; De Nardi et al. 2010). The life-cycle model can be extended in several directions to account for these observations and to provide a more realistic description of the saving behavior of the elderly.

\subsection{A Life-Cycle Model with Lifetime Uncertainty}

If individuals are uncertain about their remaining lifetime, this might result in a slower decumulation of wealth, as was first shown by Yaari (1965) and Davies (1981). Riskaverse individuals seek to safeguard themselves from outliving their assets in case they become very old. However, the possibility of not getting old also induces individuals to consume more at the start of retirement and reduce consumption at the end of life, as the probability of surviving becomes smaller. In addition, the availability of annuity income, such as social security and pensions, insures individuals against longevity risk and reduces the need to slow down the decumulation of wealth.

In a life-cycle model with lifetime uncertainty, consumption and saving choices depend on two behavioral parameters: the subjective discount rate and the degree of relative risk aversion. ${ }^{1}$ Individuals prefer a high level of consumption at the start of retirement if their discount rate is larger than the real interest rate. Frederick et al. (2002), using experimental data to estimate the discount rate, report that the discount rate surpasses the real interest rate-implying that individuals behave impatiently and that consumption declines with age. Mortality risk is an important determinant of

\footnotetext{
${ }^{1}$ The referred model assumes that persons have a utility function that is of the constant relative risk aversion (CRRA) form. This is widely used for modeling saving behavior under uncertainty, since it allows for the precautionary motive for saving.
} 
saving because it increases the effective discount rate. Since mortality risk increases exponentially as individuals grow older, individuals prefer earlier consumption, and the level of consumption and wealth will further decline with age. The degree of relative risk aversion measures the willingness to alter consumption in response to a change in mortality risk. Risk-averse individuals respond more cautiously to variations in mortality risk. They consume less at the start of retirement and hold more wealth at every age against the risk of living very long — ending up with little more than their annuity income. Of course, with a sufficiently high annuity income there is less need to live frugally; also risk-averse individuals will deplete their wealth at an early age.

Mortality risk is usually measured by life-tables that report the probability of death for the entire population in the next year, for a given age and gender. These life-tables do not account for other important determinants of mortality risk such as socioeconomic status and health status. Differential mortality by socioeconomic status is observed in many studies; Attanasio and Hoynes (2000) and Hurd (2002) show, for example, that wealthier individuals have the tendency to live much longer than poor individuals in the US. Kalwij et al. (2013) show that differential mortality is also an important phenomenon in the Netherlands. As a result, it is impossible to understand saving behavior by observing wealth holdings in cross-section because wealth will increase artificially with age (as was first raised by Shorrocks 1975). Similarly, individuals born in different periods in time might have different levels of wealth due to productivity differences between cohorts or policy changes that affect specific cohorts. For example, Kapteyn et al. (2005) report the importance of the introduction of the old-age pension system in the Netherlands to explain wealth differences between cohorts.

To assess whether the elderly decumulate their wealth, you therefore need to follow the same households - that do not leave the sample due to death or a change in family situation-over a period of time. The change in wealth holdings within the same surviving households will be unaffected by differential mortality or cohort effects (see e.g. Hurd 2002). However, in case of differential mortality, the level of wealth holdings - among this selected sample of surviving households - will increase with age. By weighting the data using wealth-dependent mortality rates, the level of the wealth-age profile can be corrected. This approach applied by Attanasio and Hoynes (2000), is contingent on rather strong assumptions. An alternative solution is to stratify the sample by household wealth, as applied by Hurd (1987), for example.

\subsection{A Life-Cycle Model with Bequests}

Although a life-cycle model with mortality risk predicts a slow decumulation of wealth if individuals are risk averse, it does not explain why many elderly do not decumulate their assets at all-even at the end of life. A possible explanation is that parents derive utility from leaving a bequest. Hurd (1989) formulates a life-cycle model with intentional bequests. This contrasts with accidental bequests that arise in a model with mortality risk. An intentional bequest motive reduces consumption at the start of retirement and leads to a lower level of consumption in retirement such that more wealth is held at every age. 
Hurd's model focuses on retired individuals, such that retirement choices do not have to be explained. Moreover, retirees face no risk of reduced income due to unemployment, which is an important risk factor for elderly workers close to retirement. Individuals receive a certain stream of annuity income and are not able to annuitize their wealth. This is consistent with the low ownership rate of private annuities in the US and in European countries, which is partly explained by the relative high importance of pension and social security wealth in the household portfolios of most retirees (see also the overview of Benartzi et al. 2011, for other compelling reasons). The model also assumes that borrowing is restricted, in the sense that individuals must always have a positive level of wealth. This implies that banks only provide loans that are secured against collateral such as a mortgage loan. Without imposing liquidity constraints, Mariger (1987) shows that individuals with a low degree of risk aversion, who do not plan to leave a bequest, desire to borrow against future pension income as the prospect of death increases.

The model considers single-person households. For a two-person household, uncertain lifetimes complicate the model considerably because consumption becomes conditional on the expected lifetime of the spouse. In addition, the income of the surviving spouse is most likely different from the income as a couple. In both cases, the couple has to secure sufficient resources for the surviving partner as well as for the planned bequest after the death of the surviving spouse. Another complexity is the existence of returns-to-scale in consumption for couples. If the couple shares many resources, the surviving spouse is, all else equal, worse-off if the partner dies. Hurd (1999) describes the optimal consumption path for elderly couples, which is computational burdensome: to derive the consumption path for elderly couples, the consumption path of the surviving spouse first has to be solved at every age and for each spouse separately. Browning (2000) uses an even more elaborate model in which both partners have independent preferences and have to agree on the level of consumption. The model builds upon the notion that wives are typically younger than their husbands and that they have a higher life expectancy. Therefore, wives have a stronger incentive to save than their husbands. Browning (2000) shows that the higher the relative income share of the wife, the higher the accumulated assets should be, all else equal. Because of the complexity of retirement saving behavior, most empirical studies examine it from the perspective of a single-person household. The work of Lillard and Weiss (1997) is an exception, however; they abstract from important sources of uncertainty which leads to somewhat unsatisfactory results.

In the model, Hurd (1989) further assumes that the marginal utility of leaving a bequest is constant. This assumption results in a closed-form solution of the utility function. This makes the model easier to solve, but leads to the somewhat unrealistic conclusion that bequests are not altruistic, in the sense that they are not motivated by the economic wellbeing of the children. The altruistic bequest motive predicts that the elderly plan to leave a bequest if they expect their children to be less well-off (Becker and Tomes 1979). Laitner and Juster (1996) provide empirical evidence that planned bequests are indeed larger for parents who have children with relative low lifetime earnings. Hurd justifies this assumption with the argument that bequests are typically a small fraction of the lifetime wealth of the children and therefore only result in a slight adjustment of the marginal utility of the children. It should be noted that this is 
also consistent with an egoistic bequest motive-in the sense that the accumulation of wealth provides utility by itself: for example, if people are thrifty or derive social status out of wealth.

Another drawback of the assumption of a constant marginal utility is that consumption is independent of the level of wealth at the start of retirement. As a result, wealthy persons bequeath all savings above a certain threshold level of initial wealth and do not increase consumption. For higher levels of initial wealth this might even result in rising wealth profiles. Carroll (2000) and De Nardi (2004) propose a less restrictive functional form of the bequest function where bequests are a luxury good such that wealthier persons devote a larger part of the wealth holdings to a bequest. In addition, there is a minimum level of wealth under which the household leaves no bequests. Whether or not the household leaves a bequest also depends on the degree of altruism. This functional form is widely used in the recent savings literature; see e.g. De Nardi et al. (2010), Ameriks et al. (2011), Lockwood (2012).

To test whether the bequest motive is prevalent, Hurd fits the life-cycle model to data from the Retirement History Survey (RHS) for the years 1969-1979. The model is, however, not able to distinguish between the wealth trajectory of a person with a bequest motive who has a low degree of risk aversion and a risk-averse person who does not plan to leave a bequest. Hurd assumes that only individuals with children have a bequest motive. As a measure of wealth, both net worth and net financial wealth (which excludes illiquid housing equity) are considered. The results support a lifecycle model with lifetime uncertainty, but there is no evidence that individuals with children behave according to a bequest motive. ${ }^{2}$ The wealth profiles of individuals with and without children are very similar. Kopczuk and Lupton (2007) use a less stringent assumption to identify the bequest motive. They allow all households to have a bequest motive, independent of whether or not they have children, and show that many elderly households behave according to a bequest motive.

The evidence against the presence of a bequest motive by Hurd is only valid if bequests take place after the death of the surviving spouse. Most elderly singles have lost their partner and it is possible that some of the estate was already split between the surviving spouse and other heirs. For example, Poterba et al. (2011) show that widowhood results in a sharp drop in wealth holdings for the surviving spouse, and Hurd and Smith (2001) report that $80 \%$ of the estate (which generally excludes the house) is transferred to the children upon widowhood. In addition, parents might prefer to transfer wealth during their lifetime to support their children when they need it most-for example, to alleviate borrowing constraints when they buy their first house or to support them in case of earnings loss. Empirical evidence by McGarry (1999) indicates that lifetime transfers are important for US families, while Ando and Guiso (1994) find no evidence for Italian households, who are known to have strong family ties.

\footnotetext{
2 The estimated coefficient of relative risk aversion of 0.73 is considerably smaller compared to what is usually found in the literature, and predicts that retirees will exhaust their wealth at a relative early age. The estimated coefficient of the subjective discount rate of 0.05 is larger than the assumed interest rate of 0.03 . This means that the elderly behave impatiently, which results in even faster decumulation of wealth. The exclusion of housing equity does not significantly alter the results.
} 
The limited strength of the bequest motive is consistent with survey evidence about motives for saving. For example, Dynan et al. (2002) report that the vast majority of retired US households mention precautionary reasons, such as illness or emergencies, as a motive to save, while saving for a bequest is rarely mentioned. Very similar results are found for the Netherlands, even though saving for illness is less urgent because of the comprehensive coverage of the health insurance system (Alessie et al. 1999). Nevertheless, many people state that they expect to leave a bequest, and a significant portion of the children receives an inheritance (Hurd and Smith 2001). A possible explanation is that savings for precautionary reasons will ultimately be bequeathed if no unforeseen events occur (Dynan et al. 2002). Thus, savings serve a dual role and the importance of both motives cannot be distinguished without additional information. Ameriks et al. (2011) designed a survey question to measure the tradeoff between the size of the bequest and the amount spent on long-term care expenses-which is an important driver of precautionary saving in the US. Their result indicates that intended bequests are an important reason to save.

\subsection{A Life-Cycle Model with Uncertain Health Expenses}

As already mentioned, precautionary savings for illness is an important motive for retirees to save. This might also explain the slow rates of decumulation among the elderly. The amount of risk that the elderly face in case of illness depends on the coverage of health insurance and the availability of social insurance programs.

The importance of uncertain health expenses for saving in old-age was first examined by Kotlikoff (1989). Using a two-period savings model, Kotlikoff shows that partial insurance for severe health problems, such as a prolonged stay in nursing home, is an important reason for middle and upper income households to save. For low-income households, the relatively high costs of medical care in conjunction with the availability of social insurance programs such as Medicaid in the US reduce precautionary savings. These programs secure a subsistence level of consumption for individuals with high out-of-pocket medical expenses. The programs do require individuals to first run down assets, to become eligible. The existence of an asset-test further discourages saving among low-income households. Hubbard et al. (1995) show in a simulation study that the asset-tested safety-net is one of the main reasons why many low-income US households save so little, even close to retirement.

An important assumption in Kotlikoff's model is that the marginal utility of consumption declines in poor health, because individuals are no longer able to consume as much as they desire. This reduces both the level of savings and the desired coverage of health insurance. The direction of the effect can, however, also be positive; see e.g. Finkelstein et al. (2013). For example, the derived utility from hiring a housekeeper or investing in home adaptations will most likely increase in poor health. Finkelstein et al. (2013) provide empirical evidence that the marginal utility of consumption is lower among individuals with chronic diseases compared to their healthy counterparts. This is consistent with the empirical observation that wealth holdings of the elderly increase with age in countries with comprehensive health insurance coverage; see e.g. BörschSupan and Stahl (1991) and Alessie et al. (1999) for German and Dutch evidence on 
this issue. This is because consumption needs fall below the level of pension income when health deteriorates. Moreover, individuals are unable to borrow against future pension income at the start of retirement, when they have no health problems.

Properly understanding the importance of uncertain health expenses for saving behavior requires precise information about the incidence of large out-of-pocket expenses (similar to the necessity of life-tables to measure mortality risk). The probability distribution of health expenditures strongly depends on age and health status, but may be influenced as well by characteristics such as income and gender. Kotlikoff makes no attempt to precisely measure these risks. Feenberg and Skinner (1994) use information about medical deductions in a longitudinal dataset of US tax records from 1968 to 1973 to estimate the distribution and persistence of out-of-pocket health expenses. Their estimates indicate that health expenses are highly persistent, which reflects the risk of chronic conditions. They also find that health expenses represent a greater proportional risk to low-income households, which implies that they should save more in absence of a social insurance program. French and Jones (2004) use more recent data on out-of-pocket expenses from the HRS between 1992 and 2000. They construct an alternative econometric model that fits both the mean and the upper tail of the empirical distribution of health expenses to better measure the risk of catastrophic health expenses. The parameter estimates of the fitted model are used to simulate lifetime medical expenses. They find that the elderly run a large risk of excessive out-of-pocket health expenses. About $1 \%$ of the elderly receive a health shock at retirement that results in a present value of lifetime health expenses of more than $\$ 43,500$. This is substantially more risk than indicated by the model of Feenberg and Skinner (1994), and has important implications for the level of precautionary savings among the elderly. There are some concerns that self-reported health expenditures are overstated in the HRS, which increases the estimated health expenditure risk (Venti 2011).

Subsequent studies by Palumbo (1999) and De Nardi et al. (2010) examine the importance of out-of-pocket health expenditures for precautionary saving by incorporating the estimated health expenditure risk in a life-cycle consumption model. Their models are based on the retirement phase of the framework of Kotlikoff (1989) and Hubbard et al. (1995). They estimate the structural parameters (such as the coefficient of relative risk aversion, the discount rate, the bequest motive and the health state dependent utility) such that the predicted wealth-age profile of their simulated model closely resembles the empirical wealth-age profile. Palumbo uses data on consumption and health status from the Panel Study of Income Dynamics (PSID) for the years 1984 through 1986 and uses external data sources to measure health expenditure uncertainty. Palumbo argues that in particular the risk of a prolonged stay in a nursing home explains the limited decumulation of wealth in old-age. He does not find evidence for health state dependent utility.

De Nardi et al. (2010) extend the model by allowing for differences in saving behavior between the income-poor and the income-rich, and by accounting for wealth differences between cohorts and differential mortality. They accomplish this by simulating the life-cycle model for different cohorts (with different levels of initial wealth) and by matching the wealth-age profile for different permanent income quantiles and cohorts. The bias due to differential mortality is further reduced by not using population 
life-tables_-and instead allowing mortality risk to differ by permanent income, gender and health status. The data stem from the HRS for the years 1996 through 2006. They use the method of French and Jones (2004) to measure health expenditure risk. Their measure of wealth includes both financial assets and illiquid housing equity. They match the median of wealth rather than means because medians are less sensitive to outliers. This implies that the behavioral parameters of 'an average' household are matched well. The model might be less successful in capturing the behavior of very wealthy households, who might save a large part of their wealth to leave a bequest.

De Nardi et al. (2010) neither find evidence in favor of a bequest motive nor health state dependent utility. The estimated coefficient for relative risk aversion is considerably larger than the one from the model of Hurd (1989). This suggests that health expenditure risk is an important driver of precautionary savings for the higher permanent income groups. Those who have a low permanent income have no incentives to save because they are relatively well protected by the government-provided (assettested) safety-net. In addition, out-of-pocket health expenditures are relatively low for the income-poor. The safety-net is also important for the income-rich because they face potential large out-of-pocket health expenditures late in life.

\subsection{Housing and Portfolio Choice}

While the theories discussed above can explain empirical deficiencies such as the flat wealth profiles, even until advanced ages, they do not account for the fact that the elderly keep a large amount of their wealth in the form of illiquid housing equity (see, among others, Sheiner and Weil 1992; Poterba et al. 2011). The evolution of housing wealth might be different from the evolution of other kinds of wealth, since a house is both an asset and a consumption good. If desired housing consumption is constant throughout retirement, this will cause housing wealth to decline more slowly than other kinds of wealth if the ability to extract housing equity is limited (Henderson and Ioannides 1983).

Households can disentangle the wealth part and consumption part of housing in different ways. First, households can borrow in the form of a second mortgage or take a reverse mortgage. A reverse mortgage allows the household to withdraw a lump sum or receive an annuity payment or a combination of both. The household is able to remain in their home as long as it is their permanent residence. They pay off the accumulated debt when the last household member dies or leaves the house permanently - for example, to go to a nursing home. The lender takes the loss if the value of the debt exceeds the value of the house (but also receives the appreciation in the house value). The demand for reverse mortgages is low among the elderly. This is usually explained by the existence of a bequest motive (e.g. Davidoff 2010; Lockwood 2012). This is puzzling, however, because borrowers are also able to withdraw only a part of their housing equity. The complexity of reverse mortgages and the relative high costs_-partly to compensate the lender for the risk—are other possible reasons. As a result, households can extract relatively little housing wealth. Sinai and Souleles (2008) calculate that about half of the value of the house can be withdrawn as a lump sum for households at the beginning of retirement. This amount increases for older age groups. 
Bridges et al. (2006) provide evidence that housing equity withdrawal nowadays occurs more often among elderly households. This might be related to financial innovations in the mortgage market over the last decade, such as the introduction of interest-only mortgages, which allow liquidity-constrained elderly households to better smooth consumption after a financial shock. The obvious concern is that increasing mortgage debt holdings make the elderly more vulnerable to housing price risks; see also Van Ooijen and Van Rooij (2014) for a discussion about mortgage risks.

Households can also extract housing equity by selling the house and becoming a renter or by purchasing a less expensive house. Relatively few households extract equity by moving to a less expensive house in later life, as documented by Sheiner and Weil (1992) and Venti and Wise (2000). This implies that a considerable amount of equity is not used for consumption purposes. There are several potential explanations for the low turnover rate among elderly people. First, the elderly might want to bequeath the house to their children. The evidence about the importance of a bequest motive is, however, not particularly strong. Second, households may use their housing wealth as a buffer against catastrophic shocks such as the death of the spouse or uncertain medical care at the end of life. They leave the remaining wealth as an incidental bequest. Suggestive evidence in favor of this explanation is provided in a recent study by Ameriks et al. (2011). Third, moving involves not only large monetary costs but also emotional costs of settling into a new environment. Venti and Wise (2000) use survey questions which indicate that the elderly are indeed very accustomed to their house and have no intention of moving to a smaller house. Rouwendal and Thomese (2013) show that homeowners are more attached to their house and are less likely to become institutionalized even if health deteriorates.

The issue of adjustment costs associated with housing wealth and consumption behavior was recently investigated by Chetty and Szeidl (2007). They develop a life-cycle model in which households derive utility from housing and non-housing consumption such as clothing and food. Households are unable to extract equity from the house or to adjust the size of the house without selling the house and incurring adjustment costs. Households are willing to incur the adjustment costs only when a large permanent shock occurs (such as death of the spouse or deteriorating health). As a result, they are more averse to smaller risks and keep a buffer of financial assets for incidental expenditures. When confronted with a small health shock, households first draw down their liquid assets before downsizing their home equity. Davidoff (2010) argues that since the desired level of housing consumption also declines after a large health shock, housing equity serves as an ideal saving device for out-of-pocket medical expenditures. Yogo (2009) provides a model with health investments and adjustment costs that also predicts that households primarily dissave in the form of housing equity after a large health shock.

There are a few recent studies that empirically explore the impact of health status on portfolio allocation of the elderly using data from the HRS, thereby explicitly taking into account the presence of illiquid housing wealth. For example, Berkowitz and Qiu (2006) and Coile and Milligan (2009) show that the onset of a new chronic condition leads to a much larger decline in financial wealth than in housing wealth. They do not consider, however, the long-run effect of a health shock. Medical expenses related to a chronic condition last for a long time, which gradually drains household savings. 
Yogo (2009) finds that individuals primarily reduce housing equity in response to a large decline in self-reported health between two waves of the HRS.

Finally, Flavin and Yamashita (2002) and Chetty and Szeidl (2010) examine the effect of housing equity on portfolio choice. Their models predict that households will invest a larger share of their financial portfolio in risky assets, as their exposure to housing price risk declines. This implies that the portfolio share of risky assets increases with age, since people reduce their mortgage debt. Moreover, a smaller mortgage debt translates into lower monthly payments over the remaining term of the mortgage. These lower payments make households less vulnerable to financial shocks. Pelizzon and Weber (2009) test these predictions using Italian household data. They show that housing wealth plays a key role in financial portfolio choice.

\section{Data Sources}

We use linked administrative records from Statistics Netherlands to provide descriptive evidence about saving behavior and portfolio choice after retirement.

\subsection{Dutch Income Panel}

The Dutch Income Panel (IPO) contains detailed information on income, at both the individual and the household level, and on assets and liabilities at the household level. The data stem mainly from the National Tax register. It should be noted that the Dutch tax administration levies a wealth tax ('box 3 tax') if net financial wealth exceeds a certain threshold, which depends on marital status. ${ }^{3}$ In order to check whether people report their financial wealth in a correct way, the tax authorities require banks and insurance companies to provide relevant data on financial wealth of all their clients (data on checking and savings account balances, and on their investment portfolio). Both income and assets are therefore accurately measured.

IPO started in 1989 and consists of about 90,000 households. The unit of observation is the "key person" of a household, which is drawn randomly from the Dutch population and is followed over the life course. The dataset contains information about the key person and all household members. When the key person moves to another household or drops out of the sample because of death or migration, we lose all information of the remaining household members. The IPO is linked to the Dutch population register, which includes demographic variables such as age, gender, marital status and country of birth. We also use the population register to obtain information about the number of children and whether an elderly person resides with an adult child.

Data on financial wealth holdings are available from 2005 onwards. Therefore, we only use the 2005-2010 waves of the IPO. Due to its administrative nature, the IPO data has many advantages above other survey datasets on income and asset holdings. First, it has a very low attrition rate (due only to migration) and includes individuals who are either under-represented or not represented in most surveys (such as the rich,

$\overline{3 € 20,661 \text { for single-person households and } € 41,322 \text { for couples in } 2010 .}$ 
immigrants, single-person households, the elderly population, and individuals living in institutions). Another advantage of the data is that the observed wealth and income variables are measured with high accuracy, which is of crucial importance for studying wealth changes. In addition IPO measures precisely the following sources of pension income: social security payments (AOW), occupational pension benefits and thirdpillar annuity income. The IPO does not make a distinction between occupational pension benefits and income from privately purchased annuities. It only records the sum of these two income components. Item non-response and misreporting of assets is a serious problem when using survey data to study saving behavior. For example, Venti (2011) reports that $80 \%$ of US households who participate in the HRS misreport the ownership of bonds and more than $40 \%$ of the households provide incorrect information about the ownership of private retirement savings. This leads to large artificial changes in asset ownership and asset holdings between survey waves.

In principle, year-end values of all asset and debt items are reported in the IPO. However, there are some problems with the valuation of the owner-occupied house. Statistics Netherlands mainly bases this valuation on the WOZ value. The WOZ value, which is determined by the government, is equal to the average value of similar houses in the neighborhood that are sold during the previous calendar year. The WOZ value can therefore be seen as a good proxy for the value at the beginning of year. Statistics Netherlands has used a nationwide house price index to inflate the WOZ value in order to proxy the year-end value of owner-occupied housing. This procedure works fine for all households except for those who were homeowner at the beginning of the year but moved to a rented accommodation during the calendar year. Statistics Netherlands incorrectly assumes that people in this group are still homeowners at the end of year, and that a year-end house value should be assigned to this group of households. Fortunately, the IPO dataset contains enough information to correct this; and we have done so.

\subsection{LMR and CAK}

To measure health status of IPO respondents, we merge information from the 1995 to 2010 hospital discharge register (LMR) into the IPO dataset. The LMR contains information about hospital admission and covers all general and university hospitals and most specialized hospitals. The information includes, among other things, the main diagnosis and medical treatment, date of admission and discharge, and whether the admission is acute. The diagnosis and treatment are based on the international classification of diseases (ICD-9).

We distinguish between three categories of health: major diseases, minor diseases and the remaining group with no health problems. In case of the first type, the key person or the partner entered the hospital because of a 'severe illness'. We say that a person suffers from a 'severe illness' if they are diagnosed with cancer or cardiovascular diseases in the last three waves (i.e. wave $t, t-1$ or $t-2)$. Smith (2004) and Datta Gupta et al. (2011) identify severely ill people in a similar way. We define the second group of households to have a 'minor health condition' if neither the key person nor the partner are severely ill, but at least one of them is admitted to the hospital during 
the last three waves. The third group consists of the rest, who are not admitted to a hospital in the past waves.

Information about long-term care utilization is provided by the CAK institute, which executes financial compensation programs for long-term care users. The data contains information about the days spent in a nursing home and number of hours of nursing and personal care provided at home for the years 2004-2011.

\subsection{Sample Selection}

Our sample includes all households of which both the key person and the spouse are retired. Individuals are considered to be retired if they are at least 65 years old and receive pension income and not earnings or business income. We exclude retired individuals younger than the statutory retirement age of 65 from our sample, since early retirement might be endogenous with respect to wealth; see Van Ooijen et al. (2010) for evidence about the effect of wealth on early retirement for households in the Netherlands. We also exclude a few households that left the sample between 2005 and 2010 because of migration. We also remove those households whose key person resides with an adult child. We made this selection because IPO measures wealth at the household level. Consequently, we cannot disentangle the wealth of the parents and their adult children. For the same reason, we do not observe wealth of key persons who have permanently entered a nursing home. According to Statistics Netherlands, people living together in one nursing home form one composite household. Again, these observations are discarded. The prevalence of remarriage or divorce after retirement is very low in our sample. Moreover, in economic models explaining the saving behavior of retirees, it is typically assumed that individuals neither divorce nor (re)marry. Since we want to test the predictions of these models, we limit our sample to those households who do not change marital status other than widowhood, and thus exclude persons who remarry or divorce during the sample period. This leaves us with a sample containing 9,280 households in 2005. The sample consists of 5,047 married couples (of which 72 married couples live separately and apart because of nursing home entrance), 1,184 never-married persons and 3,049 widowed persons.

\section{Saving Behavior and Portfolio Choice of the Dutch Elderly}

\subsection{Economic Resources After Retirement}

Retired households have three important sources (of income and wealth) to support consumption during retirement. They depend on private savings and annuity income which they have built up during working life. In addition, they receive income from accumulated wealth holdings such as interest income, dividend payments and capital gains. Homeowners also receive implicit income from housing services, since they do not have to pay rent.

Annuity income consists of three components. In the Netherlands, all residents receive a state pension (AOW) at the statutory retirement age of 65 . The benefit level is equal to the minimum wage for a two-person household, while a single-person 
household receives $70 \%$ of the minimum wage. Unlike the US Social Security system, the benefits do not depend on the work history. As a result, the poverty rate is very low among the elderly. Less than $3 \%$ of the Dutch retirees receive a state pension below the poverty line (Soede 2012), while Poterba et al. (2012) show that about one-third of single-person households in the US lives in poverty in the last year of life. In addition to social security, the large majority of retirees are covered by an occupational pension scheme (Bovenberg and Gradus 2008). Participation is mandatory when the employer offers a pension scheme. The pension scheme is predominantly of the defined-benefit type, and promises a replacement rate of $70 \%$ of average earnings. The accrued pension rights depend on the years of work. In the Netherlands, pension funds do not offer the option to cash out pensions in the form of a lump-sum payment; also in countries such as the US and Switzerland, which offer the option of a lump-sum payment at retirement, the large majority of individuals choose not to cash out (Benartzi et al. 2011). Finally, retirees receive annuity benefits from privately purchased life insurance. The contributions are tax-deductible for individuals with income over which no pension rights are accumulated (such as the self-employed).

Because of the generous social security and pension benefits we consider not only private wealth, but also social security and pension wealth. The present discounted value of social security and pension wealth depends on the (joint) life expectancy of the household members, the assumed discount rate, and the ratio of the survivor benefits to couple benefits. In the Netherlands, the spouse usually receives $70 \%$ of the couple benefits upon entering widowhood (Brown and Nijman 2011). This allows us to compare the relative importance of both private wealth and annuity income for the economic status of the elderly. We will not examine the evolution of pension and socials security wealth in retirement because this is in general out of control once the youngest household member retires. In the Netherlands, banks usually do not allow borrowing against future pension and social security income. However, banks usually provide loans that are secured against collateral such as an interest-only mortgagealso when borrowers are at an advanced age. Furthermore, other than the survival benefit, pensions are not bequeathable. The size of these wealth measures, therefore, declines mechanically with age as the mortality risk increases. ${ }^{4}$

We distinguish between three definitions of private wealth holdings: net worth, net financial assets and housing equity. Net worth of the household is defined as the value of all assets less the value of all debts; see Wolff (1998) for a definition of household wealth. Total assets are defined as the sum of the values of the owner-occupied house, other real estate, checking and savings accounts, ${ }^{5}$ risky assets (i.e. stocks, bonds and mutual funds), business wealth and other assets such as cash in hand and loans to family members. Total debts are defined as the sum of mortgage debt, business debt

\footnotetext{
4 We use the formulas of Alessie et al. (1997) for the computation of pension and social security wealth. We use cohort-specific life-tables from Statistics Netherlands. We assume that the remaining lifetimes of the key person and spouse are independent. The discount rate is $3 \%$ and survivor benefits equal $70 \%$ of the couple benefits. The maximum lifespan is 110 years.

5 Financial institutions are not obliged to report to the tax administration bank account balances less than 500 euro. Consequently, IPO slightly underestimates ownership of bank accounts at the household level.
} 
and other debt. ${ }^{6}$ Housing equity is equal to the value of the owner-occupied house minus the remaining mortgage debt. Net financial wealth equals net worth minus housing equity. These measures do not include durable goods (such as cars) or the cash value of privately bought life insurances.

In the Netherlands, mortgages are commonly linked to a life-insurance policy: so-called endowment mortgages. For these products, the mortgage debt remains constant over the term of the mortgage loan, in order to take advantage of the generous tax-deductibility of the mortgage interest. The owner pays interest over the mortgage principal and an insurance premium to a life-insurance policy which covers the mortgage principal at the end of the loan. Since the cash value of the life-insurance policy is not observed in the data, housing equity is underestimated for these households. The ownership rate of endowment mortgages is, however, very low among elderly homeowners; see Van Ooijen and Van Rooij (2014). The most common mortgage among elderly homeowners is an interest-only mortgage where the borrower pays interest but does not repay the principal.

\subsection{Household Wealth Holdings in 2005}

We first examine the economic status of households after retirement in 2005. This is well before the stock markets reached rock bottom in September 2008 after the bankruptcy of Lehman Brothers, which led to the financial crisis. Table 1 reports on the distribution of household wealth across different age groups and marital status of the key person at the end of 2005. We distinguish between married couples, widowed persons and non-married persons (i.e. never married or divorced).

We first look at married couples. The average net worth of married couples in their early retirement years (age 65-69) is equal to $€ 267,400$. Not surprisingly, the distribution of wealth holdings is skewed to the right: mean net worth equals somewhat more than one and a half times median net worth. This implies that a large fraction of net worth is owned by the very rich. Notice also that median net worth declines with age from about $€ 159,000$ for the 65-69 age group to about $€ 67,000$ for the $85+$ group. At the same time, mean net worth remains fairly constant with age. This indicates that wealth inequality increases with age. Housing equity is the most important component of the household portfolio for married couples at the start of retirement: its average value is equal to $€ 149,000$. About $55 \%$ of the couples in the sample own a house in their early retirement years. This is a sharp increase compared to the ownership rate in the beginning of the 1990s. Alessie et al. (1995) document that approximately $23 \%$ of the 65-69 age group own a house in 1991 . Nevertheless, the homeownership rate is still considerably lower than that of the US, where more than $90 \%$ of the just-retired couples own a house (Poterba et al. 2011). The low homeownership rate is still prevalent among the older generation of retirees. Approximately $30 \%$ of the married couples age 85 and older own a

\footnotetext{
6 Other debt is only known for those households who pay wealth tax ('box 3 tax'). Consequently, the debt ownership is underestimated. However, data from the DNB Household Survey (DHS) indicate that the overwhelming majority of the 65+ households do not hold any form of consumer credit; see Alessie et al. (2002).
} 
Table 1 Household wealth in 2005 by marital status (cross section)

\begin{tabular}{|c|c|c|c|c|c|c|c|c|c|c|c|c|}
\hline \multirow{2}{*}{$\begin{array}{l}\text { Wealth and } \\
\text { age group }\end{array}$} & \multicolumn{4}{|c|}{ Married couple } & \multicolumn{4}{|c|}{ Widowed } & \multicolumn{4}{|c|}{ Never-married } \\
\hline & $\mathrm{N}$ & Own & Mean & Median & $\mathrm{N}$ & Own & Mean & Median & $\mathrm{N}$ & Own & Mean & Median \\
\hline \multicolumn{13}{|l|}{ Net worth } \\
\hline Age $65-69$ & 1331 & 96.7 & 267.4 & 158.6 & 369 & 91.6 & 193.6 & 41.6 & 390 & 84.6 & 139.1 & 13.7 \\
\hline Age $70-74$ & 1591 & 97.9 & 242.8 & 136.7 & 569 & 90.7 & 150.5 & 24.9 & 321 & 91.6 & 184.0 & 20.0 \\
\hline Age $75-79$ & 1226 & 98.4 & 235.3 & 99.8 & 777 & 93.3 & 142.2 & 24.9 & 217 & 93.1 & 188.2 & 24.3 \\
\hline Age $80-84$ & 687 & 98.7 & 248.0 & 87.5 & 734 & 94.8 & 168.9 & 24.9 & 159 & 96.2 & 283.8 & 62.1 \\
\hline Age $85+$ & 212 & 98.6 & 239.1 & 66.7 & 600 & 94.5 & 156.5 & 24.9 & 97 & 92.8 & 207.8 & 24.9 \\
\hline \multicolumn{13}{|c|}{ Net financial wealth } \\
\hline Age $65-69$ & 1331 & 95.9 & 118.8 & 30.1 & 369 & 88.9 & 78.1 & 17.2 & 390 & 84.4 & 69.0 & 9.5 \\
\hline Age 70-74 & 1591 & 97.0 & 108.5 & 33.1 & 569 & 89.1 & 52.9 & 16.2 & 321 & 91.9 & 101.8 & 17.7 \\
\hline Age $75-79$ & 1226 & 97.9 & 107.3 & 37.2 & 777 & 91.6 & 68.1 & 20.2 & 217 & 92.2 & 111.8 & 15.5 \\
\hline Age $80-84$ & 687 & 97.7 & 128.1 & 42.5 & 734 & 94.0 & 94.2 & 20.2 & 159 & 96.2 & 198.7 & 35.9 \\
\hline Age $85+$ & 212 & 98.6 & 147.1 & 46.0 & 600 & 93.8 & 99.6 & 22.0 & 97 & 92.8 & 146.3 & 24.9 \\
\hline \multicolumn{13}{|c|}{ Housing equity } \\
\hline Age $65-69$ & 1331 & 54.9 & 148.6 & 103.0 & 369 & 40.9 & 115.4 & 0.0 & 390 & 28.5 & 70.1 & 0.0 \\
\hline ge $70-74$ & 1591 & 48.0 & 134.3 & 0.0 & 569 & 35.0 & 97.6 & 0.0 & 321 & 27.7 & 82.2 & 0.0 \\
\hline 5-79 & 1226 & 42.7 & 128.0 & 0.0 & 777 & 27.0 & 74.1 & 0. & 217 & 24.4 & 76.4 & 0.0 \\
\hline Age $80-84$ & 687 & 38.4 & 119.9 & 0.0 & 734 & 24.5 & 74.7 & 0.0 & 159 & 25.8 & 85.2 & 0.0 \\
\hline Age $85+$ & 212 & 30.2 & 92.0 & 0.0 & 600 & 18.2 & 56.9 & 0.0 & 97 & 19.6 & 61.5 & 0.0 \\
\hline \multicolumn{13}{|c|}{ Social security wealth } \\
\hline Age $65-69$ & 1331 & 100.0 & 225.0 & 232.0 & 369 & 94.9 & 154.9 & 1 & 390 & 99.7 & 142.4 & 150.7 \\
\hline Age $70-74$ & 1591 & 100.0 & 196.5 & 197.5 & 569 & 100.0 & 134.3 & 135.4 & 321 & 99.7 & 127.3 & 128.8 \\
\hline Age $75-79$ & 1226 & 99.9 & 158.3 & 158.0 & 777 & 100.0 & 103.3 & 102.9 & 217 & 100.0 & 98.9 & 97.6 \\
\hline Age $80-84$ & 687 & 100.0 & 120.3 & 119.6 & 734 & 100.0 & 75.8 & 78.5 & 159 & 100.0 & 75.7 & 78.5 \\
\hline Age $85+$ & 212 & 100.0 & 85.0 & 86.6 & 600 & 100.0 & 45.8 & 48.0 & 97 & 100.0 & 47.7 & 50.0 \\
\hline \multicolumn{13}{|c|}{ Pension wealth } \\
\hline Age $65-69$ & 1331 & 96.2 & 231.8 & 157.5 & 369 & 90.2 & 113.5 & 65.3 & 390 & 74.9 & 96.2 & 47.4 \\
\hline Age 70-74 & 1591 & 93.8 & 156.7 & 107.0 & 569 & 88.6 & 84.8 & 45.2 & 321 & 75.4 & 76.9 & 36.2 \\
\hline Age $75-79$ & 1226 & 90.1 & 116.1 & 70.7 & 777 & 88.3 & 64.5 & 37.6 & 217 & 72.4 & 55.5 & 24.9 \\
\hline Age $80-84$ & 687 & 90.1 & 86.6 & 47.2 & 734 & 83.8 & 45.6 & 22.9 & 159 & 71.1 & 46.3 & 25.4 \\
\hline Age $85+$ & 212 & 87.7 & 58.5 & 31.4 & 600 & 80.2 & 24.6 & 9.0 & 97 & 60.8 & 27.2 & 10.2 \\
\hline
\end{tabular}

All amounts are expressed in thousands of euros and in 2010 prices using the CPI deflator Own: ownership rate (\%)

house. This does not so much reflect the draw-down of housing equity as people age but the cohort differences, which is also documented by Van Der Schors et al. (2007). Wealth holdings are less equally distributed when housing equity is excluded. Median financial wealth amounts to about $€ 30,100$, while mean financial wealth equals $€ 118,800$; this is almost four times as high as the median. For all but 
the youngest cohort, the mean level of net financial wealth among older cohorts is higher.

Social security and pension wealth represent an important part of total wealth holdings. Together they account for more than $60 \%$ of total household wealth for the age group 65-69. This percentage was even higher in the early 1990s (Alessie et al. 1995). Almost all married couples receive occupational pension benefits on top of social security wealth. We see that the older age groups less often receive occupational pensions. Among the individuals who receive occupational pensions, there is considerable variation in pension wealth: for couples, mean pension wealth (€ 231,800) is twice as large as median pension wealth (€ 157,500). This reflects differences in lifetime income. The skewness is similar to the distribution of net worth.

Wealth holdings of single-person households are considerably lower than those of married couples. The table shows that mean net worth of married couples for the age group 65-69 is about $40 \%$ higher than for widowed persons ( $€ 193,600)$ and almost twice as high for non-married persons ( $€ 139,100)$. The wealth distribution of single person-households is also more dispersed compared to married couples. For widowed persons (age 65-69) mean net worth is almost five times as high as the median ( $€ 41,600$ ). Net worth is even more unequally distributed among non-married persons. A typical (median) non-married person in the age group 65-69 has only $€ 13,700$ in net worth and $€ 9,500$ in liquid financial assets for immediate consumption. This inequality in net worth is again partly explained by differences in homeownership, which is about 15 percentage points lower among widowed persons in the age group 65-69 (40.9\%) than it is among married couples. The homeownership rate is even lower among non-married persons; only $28.5 \%$ own a house between age 65 and 69, and the homeownership rate is less than $20 \%$ for persons age $85+$. The difference in both median net worth and the homeownership rate between widowed and unmarried households disappears at older ages.

Most single-person households at the bottom half of the wealth distribution thus highly rely on social security and pension wealth in retirement. The ownership of pension wealth is slightly higher among married couples than among widowed persons for all age groups. This implies that the vast majority of widowed persons receive a survivor pension. The ownership rate is, however, substantially lower among nonmarried persons: about $75 \%$ receive an occupational pension in the age group 65-69, with the figure dropping to only $60 \%$ of the persons age 85 and above. These results suggest that the economic status of non-married households in the age group 65-69 is lower than that of widowed persons in the same age group; for older age groups, the economic status of non-married persons increases. In the subsequent sections we will focus only on married couples and widowed persons.

\subsection{Evolution of Household Wealth Between 2005 and 2010}

The described cross-sectional distribution of wealth compounds age- and cohorteffects. The panel dimension of the dataset allows us to follow the same household over 
time. We can therefore distinguish between true age effects and cohort-time effects. ${ }^{7}$ Furthermore, we are able to account for differential mortality. We therefore restrict the sample to all households that remain intact to the end of the panel. This implies that we exclude all households where one of the members dies between 2005 and 2010 and keep a balanced panel.

Table 2 shows the evolution of wealth between 2005 and 2010 for married and widowed persons in their early retirement years for the balanced panel. These households are between 65 and 69 years of age in 2005 and between 71 and 75 years of age in 2010.

Note that mean and median wealth holdings for both married couples and widowed persons in 2005 are slightly higher compared to the same statistics in Table 1. Households with a lower level of net worth thus have higher mortality risk. The table shows that the evolution of net worth between 2005 and 2010 is largely affected by developments in the housing market and the stock market. Between 2005 and 2007, the average net worth of married couples increased by $6 \%$ : from $€ 276,100$ to $€$ 293,600 . This is in particular due to the rise in housing prices in the years before the financial crisis: the mean level of housing equity rose by $7.5 \%$ between 2005 and 2007. Wealth held in financial assets did not grow as fast over the same period: mean financial wealth rose by about $4.5 \%$ between 2005 and 2007, while the Dutch stock market index doubled over the same period. This observation that the level of financial assets remained fairly constant between 2005 and 2007 is reasonable, since risky assets are not an important component of most household portfolios. There is a large decline in net worth in the years after the economic crisis, particularly because a substantial amount of the wealth holdings of the elderly is tied up in housing equity. The wealth holdings of the elderly are thus sensitive to the volatility of housing prices in the studied period. During the financial crisis, the mean housing equity of couples declined by $15.4 \%$-from $€ 166,300$ to $€ 140,700$. As we will show below, mortgage debt is limited among the retirees. This makes a decline in housing prices less critical for the elderly, compared to younger generations who usually have a larger mortgage debt compared to the value of their property. The decline in the prices of houses mainly affects elderly homeowners who move home during the downturnbecause of deteriorating health, for example, or death of the partner. For individuals who move to another owner-occupied house, the net reduction in housing equity is limited, however, since the purchase price of the new house declined as well (Sinai and Souleles 2005). The data shows that elderly couples in the age-group 65-69 do not seem to move. The homeownership rate remains fairly constant between the years 2005 and 2010.

Mean financial wealth declined by more than $11 \%$ between 2007 and 2010, while median financial wealth declined only slightly over the same period. Apparently, net financial wealth of a typical household is not affected by the downturn of the financial markets, ${ }^{8}$ either because households sold their stocks in the first phase of the financial

\footnotetext{
7 We could not disentangle either age or time and cohort effects without making additional assumptions such as done in e.g. Deaton and Paxson (1994). This is because the age of an individual is perfectly identified by the year of birth (cohort) at a specific time.

8 In 2008 the Dutch stock market exchange lost about half of its value.
} 
Table 2 Household wealth by marital status between 2005 and 2010 for households aged 65-69 in 2005 (balanced panel)

\begin{tabular}{|c|c|c|c|c|c|c|c|c|}
\hline & 2005 & 2006 & 2007 & 2008 & 2009 & 2010 & $\% \Delta{ }^{\prime} 05-07$ & $\% \Delta{ }^{\prime} 07-10$ \\
\hline \multicolumn{9}{|l|}{ Married $(N=1074)$} \\
\hline \multicolumn{9}{|l|}{ Net worth } \\
\hline Mean & 276.1 & 289.1 & 293.6 & 270.9 & 261.1 & 253.3 & 6.3 & -13.7 \\
\hline Median & 171.0 & 184.3 & 188.4 & 182.6 & 179.8 & 163.5 & 10.2 & -13.2 \\
\hline Mean share net worth ${ }^{\mathrm{a}}$ & 29.1 & 29.9 & 30.5 & 29.8 & 30.5 & 30.6 & & \\
\hline \multicolumn{9}{|l|}{ Net financial wealth } \\
\hline Mean & 121.8 & 127.5 & 127.3 & 110.2 & 115.0 & 112.5 & 4.5 & -11.6 \\
\hline Median & 31.1 & 30.8 & 32.8 & 32.2 & 34.5 & 32.3 & 5.5 & -1.5 \\
\hline Mean share fin wealth & 11.4 & 11.6 & 11.8 & 11.5 & 12.4 & 12.7 & & \\
\hline \multicolumn{9}{|l|}{ Housing equity } \\
\hline Mean & 154.3 & 161.6 & 166.3 & 160.6 & 146.1 & 140.7 & 7.8 & -15.4 \\
\hline Homeownership rate & 57.1 & 57.6 & 57.4 & 57.1 & 56.8 & 56.6 & 0.5 & -1.4 \\
\hline Mean share housing eq. & 17.7 & 18.3 & 18.7 & 18.3 & 18.1 & 17.9 & & \\
\hline \multicolumn{9}{|l|}{ Widowed $(N=320)$} \\
\hline \multicolumn{9}{|l|}{ Net worth } \\
\hline Mean & 199.4 & 207.2 & 212.3 & 192.6 & 178.7 & 177.1 & 6.5 & -16.6 \\
\hline Median & 46.5 & 44.3 & 40.1 & 35.1 & 31.9 & 28.6 & -13.8 & -28.7 \\
\hline Mean share net worth & 28.1 & 28.0 & 28.2 & 27.5 & 27.0 & 23.5 & & \\
\hline \multicolumn{9}{|l|}{ Net financial wealth } \\
\hline Mean & 82.4 & 83.1 & 87.1 & 76.3 & 72.0 & 74.8 & 5.7 & -14.1 \\
\hline Median & 17.7 & 17.3 & 18.7 & 17.6 & 16.0 & 16.0 & 5.6 & -14.4 \\
\hline Mean share fin wealth & 11.6 & 10.9 & 11.0 & 10.2 & 10.4 & 6.3 & & \\
\hline \multicolumn{9}{|l|}{ Housing equity } \\
\hline Mean & 117.0 & 124.1 & 125.2 & 116.3 & 106.7 & 102.3 & 7.0 & -18.3 \\
\hline Homeownership rate & 42.2 & 41.9 & 41.9 & 41.3 & 41.6 & 41.3 & -0.7 & -1.4 \\
\hline Mean share housing eq. & 16.5 & 17.1 & 17.2 & 17.3 & 16.6 & 17.2 & & \\
\hline
\end{tabular}

All amounts are expressed in thousands of euros and in 2010 prices using the CPI deflator. In this table we consider a balanced panel: i.e. the same households are followed over time for which the marital status does not change between 2005 and 2010

${ }^{a}$ Mean share of total wealth (\%): total wealth is equal to the sum of net worth, social security wealth and pension wealth

crisis when prices started to fall, or because of the limited importance of risky assets in the average financial portfolio. In the next section we show that households already reduced stockownership 2 years before the financial crisis.

For widowed households we observe a similar profile for net worth, both before and after the financial crisis. The level of net worth is considerably lower compared to married couples. The median net worth profile is remarkably flat among widows because of the relative low homeownership rate. The median level of financial wealth is just below the threshold for the exemption of wealth taxation for single households, which is a finding we also have for married couples. 
(a)

(a) Married

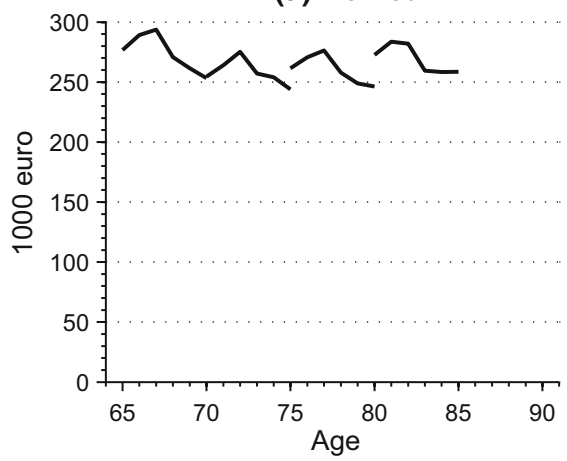

(b)

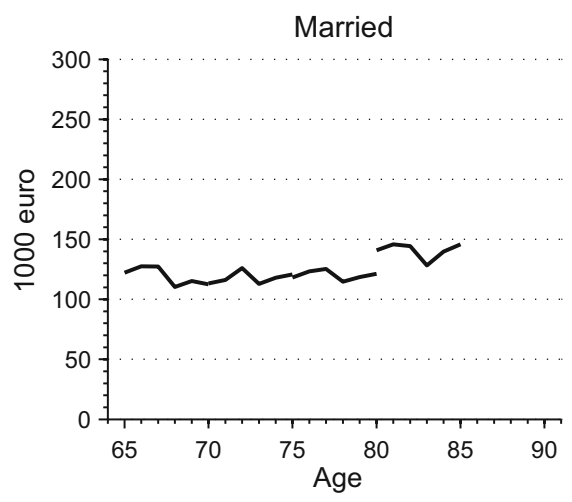

(c)

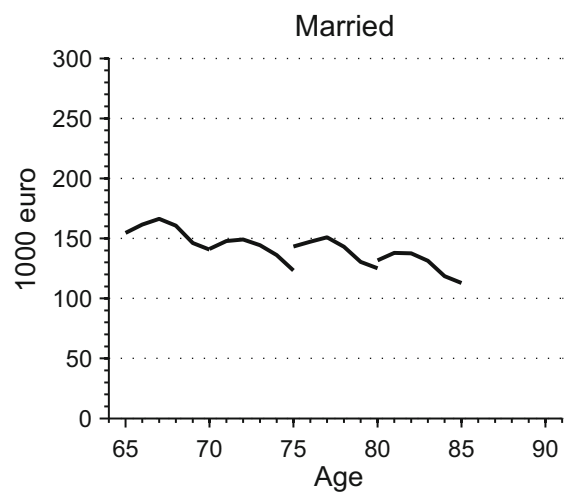

(b) Widowed
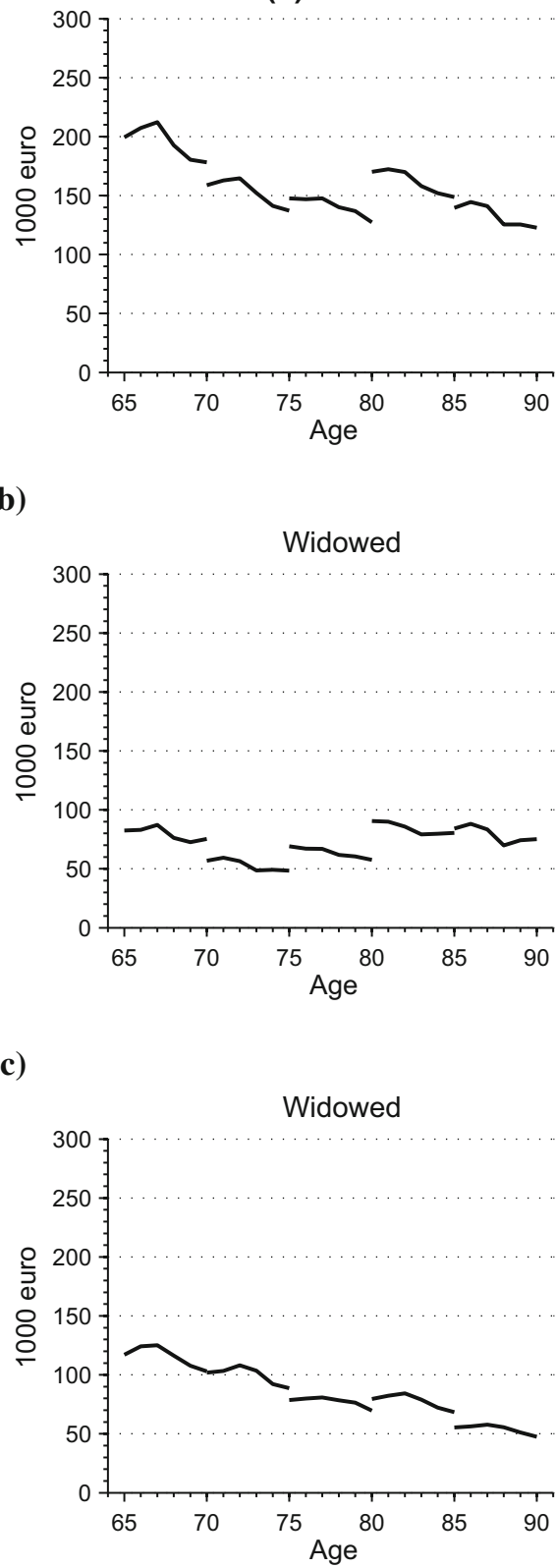

Fig. 1 Wealth profiles (mean) by cohort and age of the key person of household (balanced panel). a Net worth (mean), b net financial wealth (mean), c housing equity (mean)

Figure 1 also presents the mean wealth-age patterns for the older cohorts. In the figure, each 'cohort line' is composed out of households born in five consecutive years. The first line matches the cohort as displayed in Table 2. For married couples we use 
four cohorts, where the oldest cohort is 80 years and older in 2005 . For widowed households we use five cohorts, where the oldest cohort is age 85 and older in 2005. Since a person's year of birth is perfectly identified by his age at a specific date in time, we cannot distinguish between age and time effects without making additional assumptions. If we assume that each cohort is affected in a similar way by time effects such as developments of the stock market and housing price developments (which is not unreasonable to assume), we can discriminate between both effects by comparing the shape of the wealth-age profile of different cohorts.

We first look at the wealth-age profiles of married couples. For all cohorts we observe that net financial wealth rises slightly in the years before the financial crisis and significantly declines thereafter. For all cohorts, net financial wealth rises slightly in the wake of the financial crisis when stock markets recover. The shape of the wealthage profiles of the different cohorts is thus very similar. This suggests that time-effects dominate the picture and that age-effects are limited. There seems no evidence that married couples run down their financial wealth as they get older. Even the oldest cohort (aged 80 to $85+$ in 2005) retains their financial assets. This finding seems to be at odds with the prediction of a simple life-cycle model which says that retirees should eventually deplete their wealth holdings.

Median net financial wealth holdings are significantly lower compared to the mean (see Fig. 2). Notice also that the median level of financial wealth among the oldest cohorts is even higher compared to the youngest cohort. This might reflect differential mortality, or differences in portfolio composition between cohorts (because of the lower homeownership rate among the older cohorts). For all cohorts, median financial wealth does not decline over time and seems not affected by the financial downturn of the stock market because of the limited stock ownership in the bottom half of the wealth distribution. The pattern suggests that a typical household behaves as a buffer stock saver. They keep a target level of liquid savings for precautionary reasons-for example, in case they become ill, to replace durable goods or to support their adult children with financial strain. Households will increase savings after a financial shock until they reach the target; see Carroll (2001).

Figure 2 shows that the homeownership rate is substantially lower among the older cohorts. The jumps between the lines indicate that cohort effects are important. As households age, we observe a slight decline in the homeownership rate for all but the youngest cohort. The cohort differences in homeownership explain the differences in the shape of the median net worth profiles for couples.

For widowed persons, the profile of mean net worth is very similar compared to married couples. However, the level of net worth is significantly lower for all cohorts. For widows, we also observe for most cohorts a slight decline in the homeownership rate over time. This, reduction is not large enough to explain the level difference in homeownership between widows and married couples. In Sect. 5 we show that widowhood explains part of the difference in the level of both housing equity and net financial wealth between widowed persons and couples. The median net worth profile is very flat among widows because of the low homeownership rate. The median level of financial wealth approaches the threshold for the exemption of wealth taxation for all cohorts. It thus seems important to take account of the tax system in order to understand the saving behavior of households. 
(a)
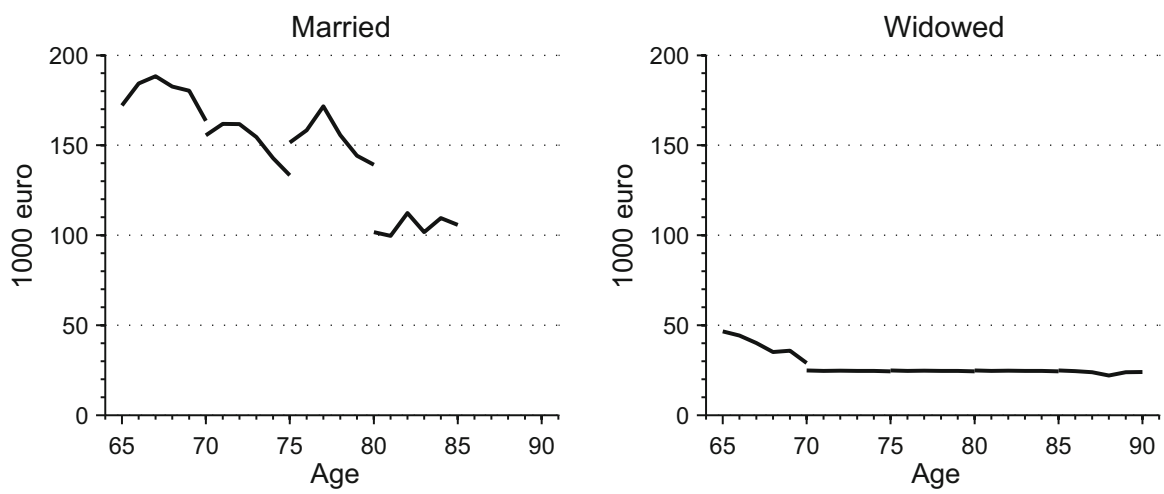

(b)
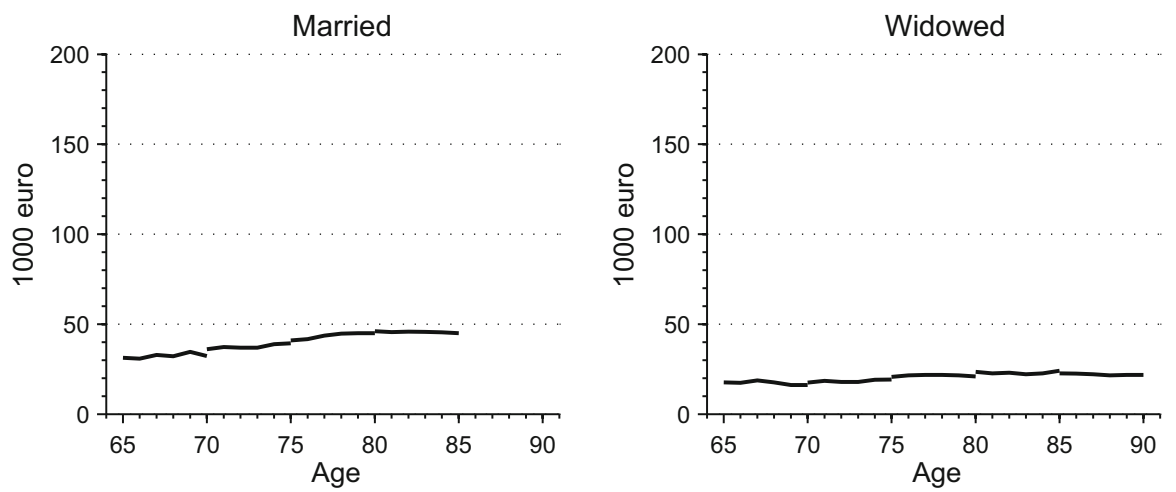

(c)
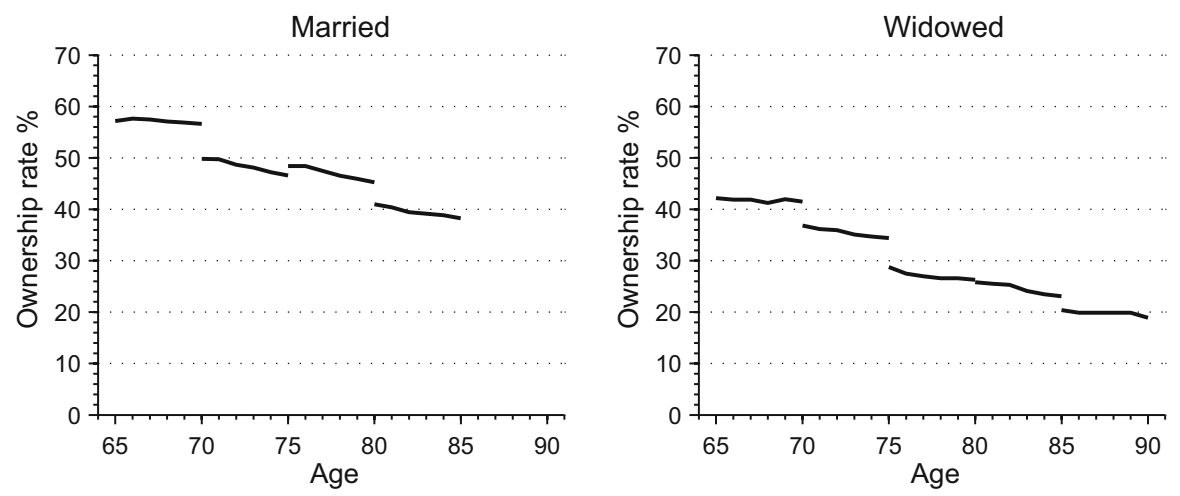

Fig. 2 Wealth profiles (median) by cohort and age of the key person of household (balanced panel). a Net worth (median), b net financial wealth (median), $\mathbf{c}$ housing equity (ownership rate) 


\subsection{Financial Household Portfolios in 2005}

Table 3 summarizes the composition of the financial portfolio for both married couples and widowed persons in 2005. For each asset and debt item, the table presents the mean value, the ownership rate and the mean portfolio share. The mean portfolio share of an asset or debt item is defined as the ratio of its value over the sum of total assets. We add together other real estate, business wealth and other assets in a single asset item. We also combine other debt and business debt in a single debt item. We refer to these portfolio components as 'other assets' and 'other debts', respectively.

Once again, the importance of housing in the composition of wealth becomes apparent. Housing is a very important wealth component especially for younger retired couples (age 65-69): 56\% of those couples own a house and its mean portfolio share is equal to $44 \%$ of total assets. Interestingly, the majority of those younger retired homeowners (36\% out of the 56\%) still have a considerable mortgage outstanding: the average loan-to-value ratio (among those who have mortgage outstanding) equals $18.3 \%$. Both the fraction of homeowners with an outstanding mortgage loan, as well as the size of the mortgage loan, are substantially lower among older age groups.

Checking and savings accounts comprise the second-most important item in the portfolio of retired couples, and this item becomes the most important component at older ages. For couples aged 65-69 these accounts represent $47 \%$ of portfolio holdings; this fraction increases to almost $70 \%$ of total assets for couples aged 85 and older. About $30 \%$ of the couples in the age range 65-69 invest in risky assets such as stocks, bonds and/or mutual funds. The ownership rate is only slightly lower among the older age groups.

Couples in the age group 85+ invest on average $9 \%$ of their total assets in risky assets. This is a larger share than younger retired couples, who invest about $5 \%$ of their financial portfolio in risky assets. This finding can be partly explained by differential mortality; the life-cycle model with uncertainty predicts that wealthier individuals invest a larger share of their assets in risky assets; see e.g. Gollier (2002). Another explanation by Flavin and Yamashita (2002) is that since the portfolio of the elderly is less dominated by risky housing equity, they can allocate a larger share of their liquid assets to stocks and mutual funds. Coile and Milligan (2009) find very similar patterns for US households with respect to the share and ownership of risky assets. The ownership rate of risky assets (excluding individual retirement accounts) is slightly higher: approximately $40 \%$ of US households in the age group 65-69 invest in stocks and bonds in $2002 .{ }^{9}$

Table 3 also presents the composition of wealth holdings among widowed persons. Homeownership is less common for widowed persons than for couples: the homeownership rate is almost 15 percentage-points lower among all age groups. In addition, widowed persons hold less mortgage debt: the loan-to-value ratio is about $14 \%$ for younger retirees and less than $2 \%$ at age $85+$. The main part of total assets is kept in checking and savings accounts. Risky assets are of minor importance: between ages 65 and 70, the ownership rate of risky assets is about $21 \%$, reducing to about $14 \%$

\footnotetext{
9 Information about dividends and capital gains in IPO (for households who pay wealth tax) indicates that among all age groups the ownership rate of risky assets was substantially higher in 2002 .
} 
Table 3 Household portfolios by marital status and age in 2005

\begin{tabular}{|c|c|c|c|c|c|c|c|c|}
\hline \multirow[t]{2}{*}{ Asset (debt) item } & \multicolumn{4}{|c|}{ Married couple } & \multicolumn{4}{|c|}{ Widowed person } \\
\hline & $\mathrm{N}$ & Mean & Own $(\%)^{\mathrm{a}}$ & Share $(\%)^{\mathrm{b}}$ & $\mathrm{N}$ & Mean & Own & Share $(\%)$ \\
\hline \multicolumn{9}{|l|}{ Age 65-69 } \\
\hline $\begin{array}{l}\text { Checking/savings } \\
\text { accounts }\end{array}$ & 1331 & 51.4 & 96.2 & 47.0 & 369 & 35.4 & 89.7 & 56.7 \\
\hline Risky assets & & 50.2 & 29.5 & 5.5 & & 21.4 & 21.4 & 5.0 \\
\hline House & & 179.7 & 55.6 & 44.2 & & 132.5 & 41.2 & 34.8 \\
\hline Other assets & & 24.1 & 14.2 & 3.3 & & 27.5 & 11.9 & 3.5 \\
\hline Mortgage & & 31.1 & 35.7 & 8.5 & & 17.1 & 24.9 & 4.8 \\
\hline Other debts & & 6.9 & 7.5 & 1.8 & & 6.1 & 7.9 & 1.1 \\
\hline Loan-to-value ratio ${ }^{c}$ & & 18.3 & & & & 13.9 & & \\
\hline \multicolumn{9}{|l|}{ Age 70-74 } \\
\hline $\begin{array}{l}\text { Checking/savings } \\
\text { accounts }\end{array}$ & 1591 & 53.2 & 97.5 & 54.0 & 569 & 30.3 & 89.6 & 62.1 \\
\hline Risky assets & & 39.4 & 26.6 & 5.5 & & 18.4 & 18.3 & 4.8 \\
\hline House & & 152.7 & 48.6 & 37.6 & & 109.4 & 35.1 & 31.2 \\
\hline Other assets & & 19.4 & 14.2 & 2.9 & & 8.5 & 7.9 & 1.9 \\
\hline Mortgage & & 18.4 & 26.5 & 4.9 & & 11.9 & 19.5 & 3.4 \\
\hline Other debts & & 3.6 & 6.1 & 1.3 & & 4.3 & 4.7 & 0.7 \\
\hline Loan-to-value ratio & & 12.6 & & & & 10.6 & & \\
\hline \multicolumn{9}{|l|}{ Age 75-79 } \\
\hline $\begin{array}{l}\text { Checking/savings } \\
\text { accounts }\end{array}$ & 1226 & 54.8 & 97.9 & 57.9 & 777 & 35.4 & 91.8 & 68.9 \\
\hline Risky assets & & 37.5 & 26.3 & 7.1 & & 22.2 & 16.9 & 5.1 \\
\hline House & & 140.5 & 42.9 & 32.1 & & 81.0 & 27.0 & 22.3 \\
\hline Other assets & & 18.4 & 13.4 & 2.8 & & 14.5 & 10.0 & 3.7 \\
\hline Mortgage & & 12.5 & 18.5 & 3.5 & & 6.9 & 10.8 & 2.1 \\
\hline Other debts & & 3.4 & 4.3 & 0.4 & & 4.0 & 4.4 & 1.0 \\
\hline Loan-to-value ratio & & 9.7 & & & & 8.7 & & \\
\hline \multicolumn{9}{|l|}{ Age 80-84 } \\
\hline $\begin{array}{l}\text { Checking/savings } \\
\text { accounts }\end{array}$ & 687 & 65.3 & 97.8 & 63.0 & 734 & 46.5 & 94.1 & 72.2 \\
\hline Risky assets & & 50.9 & 25.0 & 7.1 & & 33.9 & 16.9 & 6.2 \\
\hline House & & 129.4 & 38.7 & 27.2 & & 78.2 & 24.7 & 18.9 \\
\hline Other assets & & 15.3 & 14.1 & 2.7 & & 18.2 & 10.6 & 2.7 \\
\hline Mortgage & & 9.5 & 13.4 & 2.4 & & 3.5 & 6.8 & 1.3 \\
\hline Other debts & & 3.4 & 4.7 & 0.5 & & 4.3 & 4.1 & 0.8 \\
\hline Loan-to-value ratio & & 8.3 & & & & 5.8 & & \\
\hline \multicolumn{9}{|l|}{ Age 85+ } \\
\hline $\begin{array}{l}\text { Checking/savings } \\
\text { accounts }\end{array}$ & 212 & 79.7 & 98.6 & 68.3 & 600 & 49.1 & 94.0 & 77.3 \\
\hline Risky assets & & 50.5 & 25.5 & 9.0 & & 40.5 & 13.7 & 6.0 \\
\hline
\end{tabular}


Table 3 continued

\begin{tabular}{|c|c|c|c|c|c|c|c|c|}
\hline \multirow[t]{2}{*}{ Asset (debt) item } & \multicolumn{4}{|c|}{ Married couple } & \multicolumn{4}{|c|}{ Widowed person } \\
\hline & $\mathrm{N}$ & Mean & Own $(\%)^{\mathrm{a}}$ & Share $(\%)^{\mathrm{b}}$ & $\mathrm{N}$ & Mean & Own & Share $(\%)$ \\
\hline House & & 96.9 & 30.2 & 19.2 & & 57.6 & 18.2 & 13.1 \\
\hline Other assets & & 18.7 & 15.6 & 3.5 & & 15.6 & 11.0 & 3.6 \\
\hline Mortgage & & 4.8 & 7.1 & 1.4 & & 0.8 & 2.5 & 0.2 \\
\hline Other debts & & 1.8 & 6.1 & 0.3 & & 5.6 & 4.3 & 0.7 \\
\hline Loan-to-value ratio & & 6.3 & & & & 1.3 & & \\
\hline
\end{tabular}

All amounts are expressed in thousands of euros and in 2010 prices using the CPI deflator

a The column 'Own (\%)' reports the ownership rate of the asset (debt) item

b The column 'share (\%)' reports the average portfolio share of each asset (debt) item in 'total assets'. Total assets is the sum of checking and savings accounts, risky assets, the value of the primary residence (house) and other assets

' The rows headed 'loan-to-value' report the average of the loan-to-value ratio

above age 85 . Risky assets comprise between 5 and $6 \%$ of total assets for all age groups, which is slightly lower compared to couples. The fact that widowed persons hold less risky portfolios (with respect to both assets and debts) compared to couples might be because they possess less wealth holdings. An alternative explanation might be that the majority of widowed persons are female. Females are more risk averse and less experienced in making financial decisions regarding stock ownership; Van Rooij et al. (2011).

Table 4 shows that there is indeed a clear association between wealth and the composition of the financial portfolio. The presented information is similar to that in the previous table but the results are stratified by net worth quartile for both married couples and widowed persons (for each age group separately). For couples in the top wealth quartile, assets in checking and savings accounts are of minor importance. They hold a relatively large share of their wealth holdings in risky assets and housing wealth. The share of risky assets increases with age while housing wealth becomes less important: $66 \%$ of the younger retired couples own risky assets and $96 \%$ own a house. The homeownership rate declines to $81 \%$ among the oldest retirees in the top wealth quartile, while the ownership rate of risky assets is slightly lower (about $60 \%$ ).

For couples in the third wealth quartile we also see that housing is the dominant asset in the portfolio. The homeownership rate is more than $95 \%$ at the start of retirement and is about $40 \%$ for surviving couples who reached age 85 . The ownership of risky assets is significantly lower compared to couples in the top net worth quartile: about $27 \%$ of the younger couples own risky assets and the share of risky assets to total assets is less than $3 \%$. We again observe a shift, as individuals grow older, from housing wealth to risky assets. For the second wealth quartile we observe that housing equity is of minor importance: only $28 \%$ of the younger retirees own a house, and for the oldest age group all retirees in the second wealth quartile rent a house. Risky assets are relatively important among younger retired couples in the second wealth quartile: the ownership rate is around $21 \%$ between age 65 and age 70 , and declines to $7.5 \%$ for couples aged 85 and above. The share of risky assets is somewhat higher for the 
Table 4 Household portfolios by net worth quartiles and age in 2005-married couples

\begin{tabular}{|c|c|c|c|c|c|c|c|c|}
\hline \multirow[t]{2}{*}{ Asset (debt) item } & \multicolumn{4}{|c|}{ Ownership rate (\%) } & \multicolumn{4}{|c|}{ Portfolio share (\%) } \\
\hline & Q1 & Q2 & Q3 & Q4 & Q1 & Q2 & Q3 & Q4 \\
\hline \multicolumn{9}{|l|}{ Age 65-69 } \\
\hline Checking/savings accounts & 88.6 & 99.1 & 97.6 & 99.7 & 96.1 & 67.8 & 13.9 & 15.6 \\
\hline Risky assets & 3.6 & 21.3 & 27.0 & 66.3 & 1.3 & 5.6 & 2.4 & 12.1 \\
\hline House & 2.4 & 28.2 & 95.5 & 96.4 & 2.4 & 25.3 & 81.0 & 63.4 \\
\hline Other assets & 0.9 & 3.0 & 10.8 & 42.2 & 0.1 & 1.3 & 2.7 & 8.9 \\
\hline Mortgage & 2.7 & 25.8 & 66.7 & 47.6 & 3.1 & 11.1 & 12.8 & 6.2 \\
\hline Other debts & 1.5 & 4.8 & 7.8 & 16.0 & 4.7 & 0.9 & 0.9 & 1.1 \\
\hline \multicolumn{9}{|l|}{ Age $70-74$} \\
\hline Checking/savings accounts & 92.0 & 99.7 & 98.7 & 99.7 & 97.5 & 84.2 & 19.7 & 17.9 \\
\hline Risky assets & 4.3 & 17.3 & 25.1 & 59.7 & 1.5 & 4.9 & 4.2 & 10.9 \\
\hline House & 1.0 & 10.8 & 86.9 & 95.7 & 0.9 & 9.8 & 72.7 & 64.2 \\
\hline Other assets & 0.5 & 4.3 & 12.8 & 39.3 & 0.0 & 1.1 & 3.4 & 7.0 \\
\hline Mortgage & 1.0 & 10.3 & 56.0 & 38.8 & 1.2 & 4.4 & 8.8 & 5.1 \\
\hline Other debts & 0.8 & 1.3 & 6.3 & 16.1 & 3.4 & 0.3 & 0.6 & 0.9 \\
\hline \multicolumn{9}{|l|}{ Age 75-79 } \\
\hline Checking/savings accounts & 93.8 & 99.3 & 98.7 & 99.7 & 97.7 & 89.0 & 29.1 & 18.3 \\
\hline Risky assets & 3.9 & 17.0 & 27.4 & 56.9 & 1.9 & 7.1 & 6.5 & 12.6 \\
\hline House & 0.3 & 3.3 & 73.6 & 94.4 & 0.3 & 2.9 & 61.6 & 61.8 \\
\hline Other assets & 0.0 & 2.3 & 12.4 & 38.9 & 0.0 & 1.0 & 2.8 & 7.3 \\
\hline Mortgage & 0.3 & 2.6 & 42.0 & 29.1 & 0.4 & 1.5 & 9.0 & 2.8 \\
\hline Other debts & 0.3 & 1.6 & 3.3 & 12.1 & 0.0 & 0.4 & 0.3 & 0.8 \\
\hline \multicolumn{9}{|l|}{ Age 80-84 } \\
\hline Checking/savings accounts & 94.8 & 99.4 & 97.7 & 99.4 & 99.6 & 95.2 & 38.4 & 20.3 \\
\hline Risky assets & 1.7 & 12.8 & 27.3 & 58.5 & 0.3 & 4.2 & 8.0 & 15.7 \\
\hline House & 0.0 & 0.0 & 62.2 & 93.0 & 0.0 & 0.0 & 49.9 & 57.8 \\
\hline Other assets & 0.6 & 2.3 & 14.0 & 39.8 & 0.1 & 0.6 & 3.7 & 6.2 \\
\hline Mortgage & 0.0 & 0.0 & 32.0 & 21.6 & 0.0 & 0.0 & 7.0 & 2.3 \\
\hline Other debts & 0.0 & 0.6 & 4.7 & 13.5 & 0.0 & 0.1 & 0.8 & 1.0 \\
\hline \multicolumn{9}{|l|}{ Age $85+$} \\
\hline Checking/savings accounts & 94.3 & 100.0 & 100.0 & 100.0 & 99.4 & 93.4 & 55.3 & 26.8 \\
\hline Risky assets & 0.0 & 7.5 & 34.0 & 60.4 & 0.0 & 4.5 & 10.0 & 21.1 \\
\hline House & 0.0 & 0.0 & 39.6 & 81.1 & 0.0 & 0.0 & 30.3 & 45.2 \\
\hline Other assets & 1.9 & 3.8 & 17.0 & 39.6 & 0.6 & 2.1 & 4.4 & 6.9 \\
\hline Mortgage & 0.0 & 0.0 & 17.0 & 11.3 & 0.0 & 0.0 & 4.7 & 0.8 \\
\hline Other debts & 0.0 & 1.9 & 3.8 & 18.9 & 0.0 & 0.1 & 0.1 & 0.9 \\
\hline
\end{tabular}

The left-hand panel of this table reports the ownership rates (\%) of each asset (debt) item; the right-hand panel of this table reports the average portfolio share of each asset (debt) item in 'total assets'. Total assets is the sum of checking and savings accounts, risky assets, the value of the primary residence (house) and other assets 
younger age groups compared to the third net worth quartile (between 5 and $7 \%$ ). Couples in the bottom wealth quartile have hardly any assets other than checking and savings accounts.

For widows we also see the importance of housing wealth in the portfolios of the top wealth quartiles at the start of retirement (Table 5). However, the homeownership rate is almost zero for the oldest age group in the third wealth quartile. For the other wealth quartiles checking and savings accounts are the dominant asset category. We observe a shift from housing assets to risky assets among the older age groups in the top of the wealth distribution. The ownership rate and portfolio share of risky assets is much lower compared to couples for all wealth quartiles, which we already observed in Table 3.

\subsection{Evolution in Household Portfolios Between 2005 and 2010}

As we explained above, to distinguish between age, time and cohort effects we have to follow the asset holdings of the same cohort of households over time. Table 6 reports the participation rate in different asset classes for the cohort aged 65-69 in 2005. We follow the same cohort for 6 years. Consider first the ownership rate of risky assets among married couples: in 2005, slightly more than $31 \%$ participate in the stock market. Subsequently, this declines to $28 \%$ in 2007, and drops further during the financial crisis to a little less than $24 \%$ in 2010 . The decline in the participation rate thus already set in 2 years before the large drop in asset prices after the bankruptcy of Lehman Brothers. It is unclear whether this decline can be fully attributed to a time trend or whether age-effects explain this profile (as predicted by the life-cycle model).

Figure 3 also shows the evolution of asset classes for older cohorts spaced at 5-year intervals. The older cohorts also experience a decline in the ownership rate of risky assets over the same period. This suggests that time-effects are important and that there is little evidence that the elderly exit the stock market as they age. This is, however, inconclusive; a longer time series is necessary to make a decisive statement. Table 6 also reports the evolution of the risky assets share of total assets, which we refer to as the portfolio share of risky assets. The portfolio share of risky assets reduces only slightly as people age and seems to follow the participation profile. At the same time, the portfolio share of checking and savings accounts increases. Thus, the data suggest that the elderly rebalance their portfolio away from risky assets due to the increased uncertainty about the economic environment.

As already mentioned, the stock market participation rate among widowed persons is about 10 percentage-points lower compared to married couples in the 65-69 cohort. A comparison of the risky asset-profile among different cohorts shows that the decline in ownership slows down for the older cohorts. For the $85+$ cohort, the ownership rate stays constant at about $15 \%$ between 2005 and 2010. A possible explanation for the limited liquidation of risky assets is that the elderly start managing their portfolio more passively as their cognition declines; another explanation is that their time horizon increases due to a bequest motive.

Next, we examine the evolution of the ownership of mortgage debt and housing. For the 65-69 cohort of married couples, the homeownership rate in 2005 is about 
Table 5 Household portfolios by net worth quartiles and age in 2005-widowed persons

\begin{tabular}{|c|c|c|c|c|c|c|c|c|}
\hline \multirow[t]{2}{*}{ Asset (debt) items } & \multicolumn{4}{|c|}{ Ownership rate $(\%)$} & \multicolumn{4}{|c|}{ Portfolio share (\%) } \\
\hline & Q1 & Q2 & Q3 & Q4 & Q1 & Q2 & Q3 & Q4 \\
\hline \multicolumn{9}{|l|}{ Age 65-69 } \\
\hline Checking/savings accounts & 66.7 & 100.0 & 93.5 & 98.9 & 100.0 & 97.4 & 29.2 & 14.3 \\
\hline Risky assets & 0.0 & 7.6 & 30.4 & 47.8 & 0.0 & 2.6 & 7.0 & 8.7 \\
\hline House & 0.0 & 0.0 & 68.5 & 96.7 & 0.0 & 0.0 & 59.1 & 68.8 \\
\hline Other assets & 0.0 & 0.0 & 14.1 & 33.7 & 0.0 & 0.0 & 4.7 & 8.2 \\
\hline Mortgage & 0.0 & 0.0 & 51.1 & 48.9 & 0.0 & 0.0 & 12.0 & 5.5 \\
\hline Other debts & 0.0 & 0.0 & 9.8 & 21.7 & 0.0 & 0.0 & 2.1 & 2.0 \\
\hline \multicolumn{9}{|l|}{ Age $70-74$} \\
\hline Checking/savings accounts & 62.9 & 100.0 & 96.8 & 98.6 & 100.0 & 97.7 & 42.8 & 14.7 \\
\hline Risky assets & 0.0 & 6.3 & 21.8 & 47.2 & 0.0 & 2.3 & 7.5 & 8.5 \\
\hline House & 0.0 & 0.0 & 52.4 & 95.1 & 0.0 & 0.0 & 46.9 & 72.3 \\
\hline Other assets & 0.0 & 0.0 & 9.7 & 23.2 & 0.0 & 0.0 & 2.8 & 4.5 \\
\hline Mortgage & 0.0 & 0.0 & 41.1 & 42.3 & 0.0 & 0.0 & 8.5 & 5.1 \\
\hline Other debts & 0.0 & 0.0 & 5.6 & 14.1 & 0.0 & 0.0 & 1.1 & 1.7 \\
\hline \multicolumn{9}{|l|}{ Age 75-79 } \\
\hline Checking/savings accounts & 73.3 & 100.0 & 95.9 & 97.4 & 99.5 & 98.6 & 66.3 & 15.4 \\
\hline Risky assets & 0.5 & 4.6 & 27.1 & 38.1 & 0.5 & 1.4 & 9.2 & 9.2 \\
\hline House & 0.0 & 0.0 & 21.2 & 89.7 & 0.0 & 0.0 & 18.6 & 66.9 \\
\hline Other assets & 0.0 & 0.0 & 12.9 & 28.9 & 0.0 & 0.0 & 6.0 & 8.5 \\
\hline Mortgage & 0.0 & 0.0 & 15.3 & 29.9 & 0.0 & 0.0 & 4.1 & 4.3 \\
\hline Other debts & 0.0 & 0.5 & 4.1 & 13.4 & 0.0 & 0.2 & 1.4 & 2.2 \\
\hline \multicolumn{9}{|l|}{ Age 80-84 } \\
\hline Checking/savings accounts & 79.3 & 100.0 & 100.0 & 97.3 & 99.4 & 97.0 & 69.6 & 21.5 \\
\hline Risky assets & 0.0 & 6.6 & 22.5 & 42.6 & 0.0 & 3.0 & 9.5 & 12.7 \\
\hline House & 0.5 & 0.0 & 17.4 & 85.2 & 0.6 & 0.0 & 15.5 & 59.7 \\
\hline Other assets & 0.0 & 0.0 & 15.2 & 31.1 & 0.0 & 0.0 & 5.5 & 6.1 \\
\hline Mortgage & 0.5 & 0.0 & 10.1 & 19.1 & 0.9 & 0.0 & 3.1 & 1.9 \\
\hline Other debts & 0.5 & 0.0 & 7.2 & 10.4 & 0.5 & 0.0 & 2.0 & 1.3 \\
\hline \multicolumn{9}{|l|}{ Age $85+$} \\
\hline Checking/savings accounts & 78.0 & 100.0 & 100.0 & 98.0 & 99.8 & 99.3 & 83.0 & 25.9 \\
\hline Risky assets & 0.7 & 3.4 & 10.8 & 42.7 & 0.2 & 0.7 & 5.9 & 17.9 \\
\hline House & 0.0 & 0.0 & 1.1 & 72.0 & 0.0 & 0.0 & 0.9 & 49.1 \\
\hline Other assets & 0.0 & 0.5 & 20.4 & 30.7 & 0.0 & 0.0 & 10.2 & 7.1 \\
\hline Mortgage & 0.0 & 0.0 & 0.0 & 10.0 & 0.0 & 0.0 & 0.0 & 0.7 \\
\hline Other debts & 0.0 & 0.5 & 3.2 & 14.7 & 0.0 & 0.2 & 0.4 & 2.3 \\
\hline
\end{tabular}

The left-hand panel of this table reports the ownership rates (\%) of each asset (debt) item; the right-hand panel of this table reports the average portfolio share of each asset (debt) item in 'total assets'. Total assets is the sum of checking and savings accounts, risky assets, the value of the primary residence (house), and other assets 
Table 6 Household portfolios between 2005 and 2010, age 65-69 in 2005, balanced panel

\begin{tabular}{|c|c|c|c|c|c|c|c|c|}
\hline & 2005 & 2006 & 2007 & 2008 & 2009 & 2010 & $\Delta{ }^{\prime} 05-{ }^{\prime} 07$ & $\Delta{ }^{\prime} 07-{ }^{\prime} 10$ \\
\hline \multicolumn{9}{|l|}{ Married $(N=1074)$} \\
\hline \multicolumn{9}{|l|}{ Ownership rate $(\%)$} \\
\hline Checking/savings accounts & 96.9 & 96.0 & 98.1 & 97.3 & 98.6 & 97.9 & 1.2 & -0.2 \\
\hline Risky assets & 31.5 & 29.7 & 27.8 & 25.6 & 25.2 & 23.7 & -13.3 & -14.7 \\
\hline House & 57.9 & 58.2 & 57.8 & 57.7 & 57.5 & 57.5 & -0.2 & -0.5 \\
\hline Other assets & 14.6 & 14.9 & 14.2 & 13.7 & 14.5 & 12.8 & -2.8 & -9.9 \\
\hline Mortgage & 37.7 & 37.8 & 37.2 & 36.3 & 35.2 & 34.2 & -1.3 & -8.1 \\
\hline Other debts & 7.7 & 7.2 & 7.7 & 7.2 & 7.2 & 7.0 & 0.0 & -9.1 \\
\hline Loan-to-value ratio & 19.1 & 19.0 & 18.0 & 18.6 & 19.5 & 20.0 & -6.1 & 11.1 \\
\hline \multicolumn{9}{|l|}{ Mean portfolio share $(\%)^{\mathrm{a}}$} \\
\hline Checking/savings accounts & 55.0 & 56.0 & 56.9 & 56.8 & 59.1 & 59.9 & 3.3 & 5.3 \\
\hline Risky assets & 5.6 & 5.5 & 5.0 & 4.2 & 4.2 & 3.5 & -12.0 & -30.0 \\
\hline House & 36.1 & 35.4 & 35.1 & 35.7 & 33.8 & 34.0 & -2.8 & -3.1 \\
\hline Other assets & 3.4 & 3.2 & 2.9 & 3.4 & 2.9 & 2.7 & -17.2 & -6.9 \\
\hline Mortgage & 4.9 & 4.4 & 4.5 & 4.6 & 4.7 & 4.7 & -8.9 & 4.4 \\
\hline Other debts & 1.0 & 0.9 & 0.7 & 1.0 & 1.6 & 1.1 & -42.9 & 57.1 \\
\hline \multicolumn{9}{|l|}{ Widowed $(N=320)$} \\
\hline \multicolumn{9}{|l|}{ Ownership rate $(\%)$} \\
\hline Checking/savings accounts & 89.1 & 91.6 & 93.1 & 90.6 & 94.1 & 93.1 & 4.3 & 0.0 \\
\hline Risky assets & 22.2 & 22.5 & 19.4 & 18.4 & 17.2 & 15.6 & -14.4 & -19.6 \\
\hline House & 42.5 & 42.2 & 42.2 & 41.6 & 41.6 & 41.3 & -0.7 & -2.1 \\
\hline Other assets & 11.9 & 10.6 & 10.0 & 9.4 & 8.1 & 8.1 & -19.0 & -19.0 \\
\hline Mortgage & 25.6 & 24.1 & 24.4 & 22.8 & 21.9 & 20.9 & -4.9 & -14.3 \\
\hline Other debts & 7.8 & 8.4 & 5.6 & 5.0 & 7.2 & 5.3 & -39.3 & -5.4 \\
\hline Loan-to-value ratio & 13.8 & 13.0 & 12.4 & 12.4 & 13.3 & 13.2 & -11.3 & 6.5 \\
\hline \multicolumn{9}{|l|}{ Mean portfolio share $(\%)$} \\
\hline Checking/savings accounts & 45.0 & 44.1 & 46.0 & 46.6 & 47.8 & 48.3 & 2.2 & 5.0 \\
\hline Risky assets & 5.9 & 5.9 & 5.2 & 3.9 & 3.9 & 3.7 & -13.5 & -28.8 \\
\hline House & 46.0 & 46.7 & 45.6 & 46.2 & 44.4 & 44.3 & -0.9 & -2.9 \\
\hline Other assets & 3.2 & 3.3 & 3.2 & 3.3 & 3.8 & 3.6 & 0.0 & 12.5 \\
\hline Mortgage & 9.2 & 9.6 & 10.3 & 9.2 & 9.0 & 9.4 & 10.7 & -8.7 \\
\hline Other debts & 2.0 & 2.4 & 10.5 & 18.4 & 21.8 & 7.0 & 81.0 & -33.3 \\
\hline
\end{tabular}

In this table we consider a balanced panel: i.e. the same households are followed over time for which the marital status does not change between 2005 and 2010

a 'Mean portfolio share (\%)' reports the average portfolio share of each asset (debt) item in 'total assets'. Total assets is the sum of checking and savings accounts, risky assets, the value of the primary residence (house) and other assets

$60 \%$, and about two-thirds of the homeowners still have a mortgage outstanding. The homeownership profile stays very flat over the years. In addition, it appears that this group of young retirees redeems their mortgage at a very slow pace: mortgage ownership declines from 37.7 to $34.4 \%$ in 2010 . Similarly, the average portfolio share 
(a)
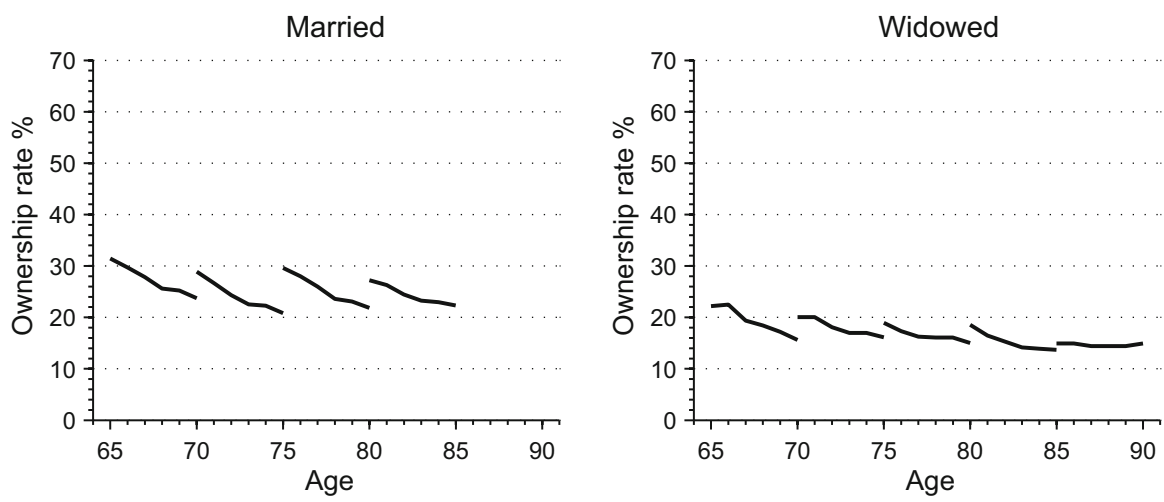

(b)
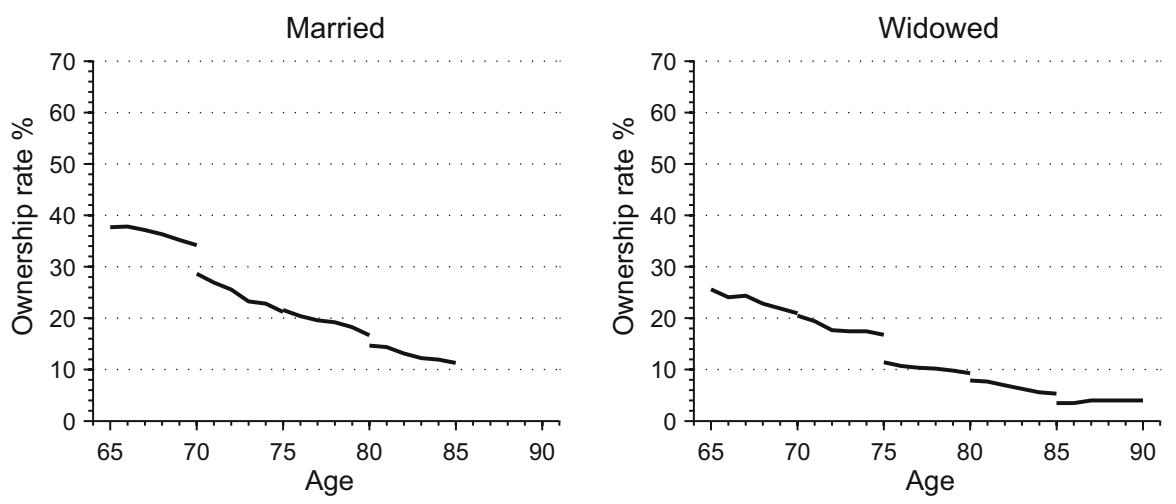

(c)
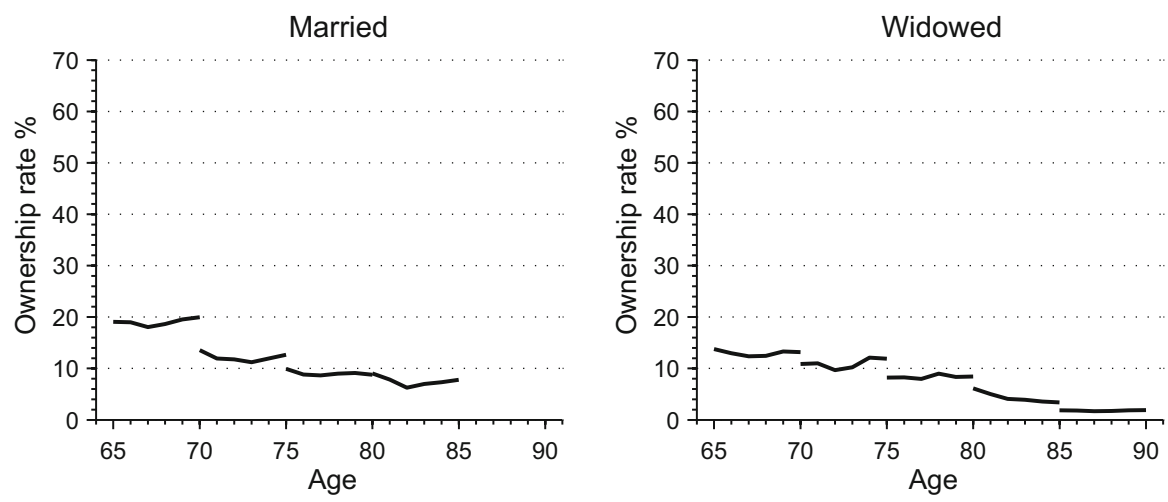

Fig. 3 Asset ownership by cohort and age of the key person of household (balanced panel). a Risky assets (ownership rate), b mortgage (ownership rate), c loan-to-value ratio (mean) 
of mortgage debt stays fairly constant over the years (around $4.7 \%$ of total assets). This is different from the behavior of US households, which seem to reduce mortgage debt after 2007 (Dynan et al. 2012). The decline in mortgage debt is mainly caused by borrowers who default on their mortgage loan. Mortgage defaults occur less often in the Netherlands and do not result in a decline of household debt. This is because mortgage loans in the Netherlands are with recourse, which means that the borrower is liable for the deficiency in case of default. Another reason for the low number of mortgage defaults is that lenders judge the affordability of mortgage payments when applying for a loan.

Figure 3 reports a more rapid decline in mortgage ownership among the older cohorts. Nevertheless, among all cohorts the loan-to-value ratios decline only slightly in the years before the financial crisis, and increase slightly after 2007 when house prices decline. This reflects the importance of interest-only mortgages for the elderly. The elderly do not pay off the mortgage principal before the end of the loan. Among the oldest cohort of couples (age 80+ in 2005), about a quarter of all homeowners still have a mortgage outstanding (10\%), with an average value of about $10 \%$ of the value of their house. This stresses the potentially important role of interest-only loans to extract housing equity for the elderly. The provision of home equity loans to elderly persons is relatively riskless for financial institutions, since the loan-to-value ratios are relatively low.

\subsection{Wealth Holdings, Financial Portfolios and Pension Income}

As shown above, a large fraction of the elderly has accumulated significant savings mainly in the form of housing equity. This holds in particular for the younger cohorts. For the bottom part of the net worth distribution and for the older cohorts, housing equity is less important: they essentially keep all of their savings in a bank account. At the median, we observe that the elderly have accumulated a decent buffer of financial wealth, high enough to cover small unexpected expenses but too small to significantly increase consumption in retirement. These households depend mainly on social security and pension income to support retirement consumption.

Table 7 shows the cross-sectional wealth distribution in 2005 by age and lifetime income tertile. We formulate lifetime income tertiles for both widows and married couples among age groups. We take the average of the sum of pension and social security income between 2005 and 2010 as a measure of lifetime income. This is a good indicator of lifetime income, since it reflects average earnings during working life. ${ }^{10}$ First of all, it is evident that wealth and lifetime income are strongly correlated. Among all age groups, couples with a higher lifetime income have accumulated disproportionally more wealth compared to individuals with a low lifetime income. Married couples between the ages 65 and 69 in the bottom income tertile have on average $€ 96,200$ in net worth, the middle quantile has $€ 172,900$ in net worth, while the upper tertile has $€ 533,700$ in mean net worth. At older ages, the difference between

\footnotetext{
10 The replacement rate for low-income groups is, however, somewhat higher compared to high-income groups.
} 
Table 7 Household wealth in 2005 by age, marital status and by tertiles of the permanent income distribution $^{\mathrm{a}}$

\begin{tabular}{|c|c|c|c|c|c|c|c|c|c|c|c|c|}
\hline \multirow{3}{*}{$\begin{array}{l}\text { Age-group } \\
\text { and assets }\end{array}$} & \multicolumn{6}{|c|}{ Married } & \multicolumn{6}{|c|}{ Widowed } \\
\hline & \multicolumn{3}{|l|}{ Mean } & \multicolumn{3}{|c|}{ Median } & \multicolumn{3}{|l|}{ Mean } & \multicolumn{3}{|c|}{ Median } \\
\hline & Q1 & Q2 & Q3 & Q1 & Q2 & Q3 & Q1 & Q2 & Q3 & Q1 & Q2 & Q3 \\
\hline \multicolumn{13}{|l|}{ Net worth } \\
\hline $65-69$ & 96.2 & 172.9 & 533.7 & 19.6 & 117.8 & 372.7 & 137.2 & 115.3 & 328.2 & 7.8 & 20.3 & 244.6 \\
\hline $70-74$ & 116.6 & 158.4 & 453.6 & 24.1 & 53.5 & 326.7 & 86.8 & 75.9 & 289.5 & 12.9 & 15.6 & 211.0 \\
\hline $75-79$ & 146.5 & 145.4 & 414.4 & 39.4 & 44.5 & 307.5 & 76.5 & 77.5 & 272.7 & 16.2 & 21.1 & 152.2 \\
\hline $80-85$ & 122.7 & 139.5 & 481.9 & 39.4 & 40.1 & 357.0 & 83.4 & 80.8 & 343.4 & 14.2 & 17.6 & 182.0 \\
\hline $85+$ & 134.9 & 125.4 & 460.3 & 25.5 & 46.0 & 291.0 & 48.4 & 70.7 & 350.3 & 15.1 & 21.2 & 109.3 \\
\hline \multicolumn{13}{|c|}{ Net financial wealth } \\
\hline $65-69$ & 32.2 & 52.8 & 271.9 & 10.2 & 28.4 & 92.4 & 77.5 & 40.9 & 116.1 & 6.0 & 12.9 & 39.3 \\
\hline $70-74$ & 46.4 & 55.7 & 223.6 & 15.8 & 27.9 & 79.5 & 30.7 & 24.7 & 103.7 & 7.7 & 13.7 & 34.7 \\
\hline $75-79$ & 68.5 & 65.4 & 188.2 & 21.2 & 29.4 & 80.0 & 41.6 & 34.4 & 128.3 & 12.3 & 17.4 & 35.5 \\
\hline $80-85$ & 59.9 & 60.8 & 263.7 & 26.4 & 32.9 & 120.5 & 49.5 & 38.0 & 195.6 & 12.4 & 16.7 & 45.7 \\
\hline $85+$ & 72.5 & 72.7 & 298.3 & 25.0 & 44.6 & 135.3 & 35.4 & 30.7 & 232.7 & 14.5 & 20.1 & 50.6 \\
\hline \multicolumn{13}{|c|}{ Housing equity } \\
\hline $65-69$ & 64.0 & 120.2 & 261.8 & 0.0 & 51.8 & 255.6 & 59.8 & 74.4 & 212.2 & 0.0 & 0.0 & 185.8 \\
\hline $70-74$ & 70.2 & 102.7 & 230.1 & 0.0 & 0.0 & 222.7 & 56.1 & 51.2 & 185.8 & 0.0 & 0.0 & 162.3 \\
\hline $75-79$ & 78.1 & 79.9 & 226.2 & 0.0 & 0.0 & 206.7 & 34.9 & 43.0 & 144.4 & 0.0 & 0.0 & 0.0 \\
\hline $80-85$ & 62.7 & 78.7 & 218.2 & 0.0 & 0.0 & 211.1 & 33.8 & 42.8 & 147.8 & 0.0 & 0.0 & 0.0 \\
\hline $85+$ & 62.4 & 52.7 & 162.0 & 0.0 & 0.0 & 0.0 & 13.0 & 40.0 & 117.6 & 0.0 & 0.0 & 0.0 \\
\hline
\end{tabular}

All amounts are expressed in thousands of euros and in 2010 prices using the CPI deflator

a Permanent income is defined as the average of the sum of pension and social security income between 2005 and 2010. We formulate permanent income quantiles for both widows and married couples among age groups

the lowest two income tertiles disappears. For widowed persons, we observe very similar patterns as for couples. Households with a low lifetime income presumably have limited possibilities to save, which results in lower levels of wealth in retirement. There is, however, considerable heterogeneity in savings within all lifetime income tertiles. We find that net worth is unequally distributed particularly among households in the lower income quartiles, for all age groups. Consider, for example, married couples aged 70 to 74 and in the highest income tertile; mean net worth ( $€$ $453,600)$ is 1.4 times higher than median net worth $(€ 326,700)$, while for households in the lowest income tertile mean net worth $(€ 116,600)$ is 4.8 times as high as the median ( $€ 24,100)$. The difference between the mean and median among persons with low lifetime income is less prevalent for financial wealth; the heterogeneity in accumulated net worth among the low-income groups is thus largely explained by housing equity: low-income households who bought a relative inexpensive house before the 1990s, accumulated substantial housing equity due to the high rates of return on housing as from the early 1990s. In addition, mortgage payments result in "forced" savings before retirement and allow them to consume more after retirement, 
when they are mortgage-free and therefore have low housing costs. For low-income groups, therefore, housing might work as a commitment device in which they are forced to save; see Thaler and Shefrin (1981). They can significantly improve their economic status in retirement by extracting housing equity to increase consumption. An important remaining question is, therefore, which factors determine homeownership status among low-income households in working life. Potential factors that reduce the demand for owner-occupied housing among low-income groups are the lower marginal tax rate, which results in lower mortgage rate deduction, and subsidized rents in the social housing sector.

Figure 4 shows the evolution of median net worth between 2005 and 2010 for widowed persons among different lifetime income groups and cohorts. The figure indicates that the profile of median net worth is very flat for all but the highest lifetime income group. A typical household in the bottom two income groups mainly holds riskless assets in checking and savings accounts, which remain rather unaffected by economic developments. Median savings are low among these groups and appear to be affected by the threshold for wealth taxation. For the highest lifetime income group, median net worth is highly affected by the rise and boom of financial markets and the housing markets. Regarding the older cohorts (age 75+), we observe that net worth already starts to decline before the financial crisis. This provides suggestive evidence that the richest households start drawing down their wealth after reaching age 75 .

These asset profiles stratified by lifetime income are completely different compared to the asset profiles in the US, as shown by De Nardi et al. (2010) for single-person households for the years 1996-2006. First of all, there is more variation in median net worth among the income quantiles in the US, compared with the Netherlands: In the US, the bottom income group has virtually no assets, while the middle income group has substantially higher assets. Second, in contrast to households in the Netherlands, US households with high incomes see net worth rise with age. The opposite is the case for households with low income. De Nardi et al. (2010) explain the observed patterns by out-of-pocket health expenses, which are unimportant for the Netherlands. The

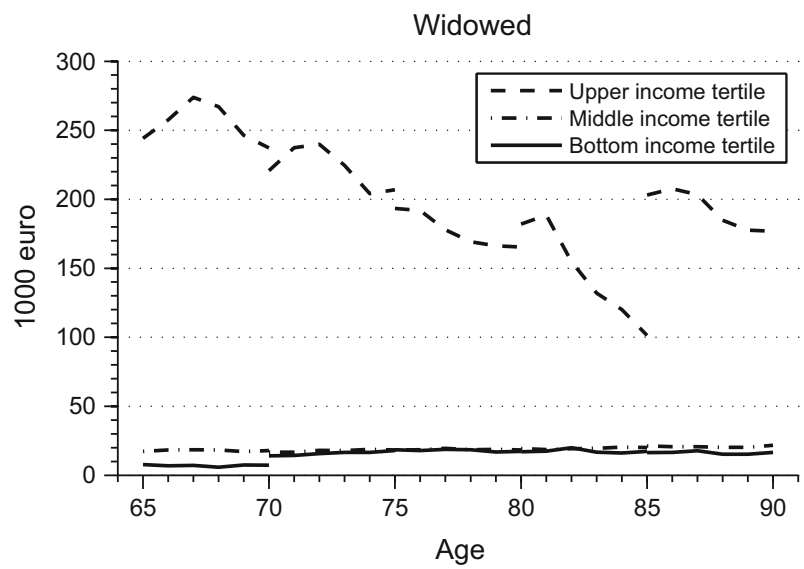

Fig. 4 Net worth profile (median) by cohort and permanent income tertile for singles, balanced panel 


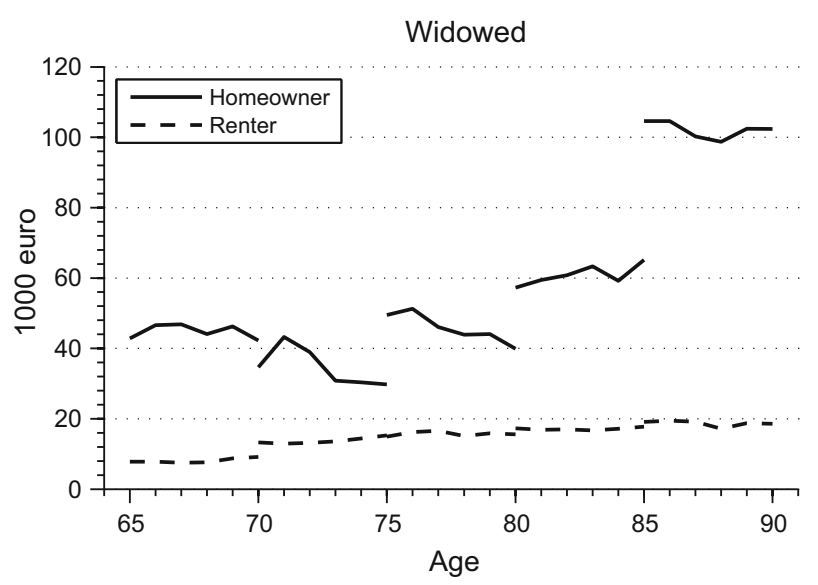

Fig. 5 Net financial assets profile (median) by cohort and homeownership status for singles, balanced panel

asset profiles might also be different because of the different periods of analysis with different economic activity. For example, we observe households before and after the downturn of the financial markets in 2008, which significantly affected asset holdings among the high-income group, while De Nardi et al. (2010) observed households in a period of higher economic growth, which might partly explain the rising wealth profile for the high-income groups. The higher prevalence of homeownership in the US might provide another explanation for the different asset patterns.

\subsection{Financial Wealth Holdings of Homeowners and Renters}

Homeownership status has an important impact on the wealth distribution among Dutch retirees. If we compare the tenure status in 2005 with the tenure status in 1989, we find that there is a strong persistence in ownership of housing, particularly among individuals in the older age groups. Among the oldest age group, less than $5 \%$ of the households who lived in a rental home in 1989 became homeowners in 2005. For individuals at the start of retirement, this holds true for about $18 \%$. These households did not gain from the large appreciation of housing prices from the beginning of the nineties up to 2007.

Figure 5 shows the profile of median net financial wealth among homeowners and non-homeowners (in 2004) for widowed persons. The figure shows that renters are considerably poorer compared to homeowners. Besides the lower accumulated housing equity, they also hold limited financial savings. This might reflect their inability to purchase a house during their working life. The figure provides no clear evidence that elderly homeowners draw down their liquid savings.

\section{Marital Transitions and Wealth Holdings}

We observe that widowed persons have much less wealth than married couples. To understand the differences in the level of wealth between widowed households and 
couples, we consider the effect of the death of a spouse on wealth holdings and the composition of wealth holdings.

Table 8 examines the evolution of private wealth by marital status transition within 2 years. ${ }^{11}$ We distinguish between three groups: married couples who survive between two waves (married-married); married couples of whom the partner dies in the next period (married-widowed); and widowed persons in two consecutive waves (widowed-widowed).

First, notice the significant difference in wealth between married couples who survive and those who lose a partner in the next period. Mean net worth of surviving couples in the age group 65-74 is $€ 260,100$ in 2005 and $€ 280,200$ in 2007, while net worth of couples of which the partner dies in the next period is $€ 191,900$ in 2005 and $€ 245,200$ in 2007. Similarly, persons who become widowed at older ages (age group 75+) are wealthier compared to those who lost their partner at an earlier age. This results in a lower level of net worth for widowed persons among all age groups. ${ }^{12}$ The difference is caused by the survival of wealthier couples.

In addition to differential mortality, there is a direct effect of widowhood on net worth. The effect of the death of a spouse on wealth holdings can be seen by comparing net worth in the period before and (1 year) after the death of the spouse. For married couples in the age group 75 or older of whom the spouse dies within the next year, mean net worth is $€ 222,900$ in 2005 and declines by $9.8 \%$ to $€ 201,000$ in the year after the death of the spouse. To interpret the magnitude of the effect of widowhood, we compare the change in net worth between surviving couples and couples in which the spouse dies in the same period. Net worth of surviving couples increases between 2005 and 2007 by $5.3 \%$ to $€ 266,700$ in 2007 . The relative decline in net worth due to bereavements is thus $15.1 \%$ (i.e. difference between -9.8 and +5.3 ). For the period between 2007 and 2009, net worth declines by $9.1 \%$ among surviving couples. Wealth declines much faster when there is bereavement. For couples who lose their spouse, mean net worth declines by $37.8 \%$. We thus find a similar net effect as in the years 2005 and 2007. For net financial wealth we even find a somewhat larger drop, presumably because this is more liquid compared to housing wealth. An explanation for the drop in financial wealth after the death of the spouse may include transfers to the children or estate taxes. In addition, wealth holdings might be lower if the collected assets from the sale of the house are less than the valuation of the owner-occupied house. Poterba et al. (2011) find less explicit effects for financial assets but strong effects for housing equity. Sheiner and Weil (1992) and Feinstein and McFadden (1989) also show that the decease of a partner is an important determinant of housing turnover.

We find that widowhood results in a significant decline in homeownership in the years after the financial crisis, but not in the period before the financial crisis; see Table 9. A possible explanation for this asymmetric effect is that widowed persons decide to sell the house sooner if future prospects about the housing market are poor or because the supply of suitable housing is larger. Moreover, it might be more likely

\footnotetext{
11 We examine the change in wealth holdings between wave $t$ and wave $t+2$.

12 The observation that widowhood at an early age is associated with lower net worth is also illustrated by the difference in net worth between continuing couples in 2005 and 2007, where mean net worth is $€$ 276,600 in 2007, and couples who are alive in 2007 and 2009, where mean net worth is $€ 290,200$ in 2007.
} 
Table 8 Marital status transition and wealth changes by year-of-birth cohort

\begin{tabular}{|c|c|c|c|c|c|c|c|c|c|c|c|c|}
\hline & \multicolumn{6}{|l|}{ Mean } & \multicolumn{6}{|c|}{ Median } \\
\hline & $t$ & $t+2$ & $\% \Delta$ & $t$ & $t+2$ & $\% \Delta$ & $t$ & $t+2$ & $\% \Delta$ & $t$ & $t+2$ & $\% \Delta$ \\
\hline & 2005 & 2007 & & 2007 & 2009 & & 2005 & 2007 & $\% \Delta$ & 2007 & 2009 & $\% \Delta$ \\
\hline \multicolumn{13}{|l|}{ Net worth } \\
\hline \multicolumn{13}{|c|}{ Aged $65-74$ in 2005} \\
\hline $\begin{array}{c}\text { Widowed to } \\
\text { widowed }\end{array}$ & 175.5 & 184.2 & 5.0 & 184.5 & 158.0 & -14.4 & 27.9 & 27.8 & -0.4 & 31.5 & 29.2 & -7.3 \\
\hline $\begin{array}{l}\text { Married to } \\
\text { widowed }\end{array}$ & 191.9 & 192.0 & 0.0 & 245.2 & 196.9 & -19.7 & 59.7 & 60.2 & 0.8 & 180.1 & 130.1 & -27.8 \\
\hline $\begin{array}{l}\text { Married to } \\
\text { married }\end{array}$ & 260.1 & 276.6 & 6.3 & 280.2 & 252.3 & -10.0 & 159.2 & 171.1 & 7.5 & 174.4 & 151.4 & -13.2 \\
\hline \multicolumn{13}{|c|}{ Aged $75+$ in 2005} \\
\hline $\begin{array}{l}\text { Widowed to } \\
\text { widowed }\end{array}$ & 154.2 & 154.6 & 0.3 & 157.3 & 141.0 & -10.4 & 24.9 & 24.7 & -0.8 & 24.7 & 24.5 & -0.8 \\
\hline $\begin{array}{l}\text { Married to } \\
\text { widowed }\end{array}$ & 222.9 & 201.0 & -9.8 & 186.6 & 116.1 & -37.8 & 47.4 & 74.2 & 56.5 & 71.5 & 36.5 & -49.0 \\
\hline $\begin{array}{l}\text { Married to } \\
\text { married }\end{array}$ & 253.4 & 266.7 & 5.3 & 274.9 & 250.0 & -9.1 & 125.6 & 132.8 & 5.7 & 146.3 & 125.3 & -14.4 \\
\hline \multicolumn{13}{|l|}{ All } \\
\hline $\begin{array}{c}\text { Widowed to } \\
\text { widowed }\end{array}$ & 162.7 & 166.3 & 2.3 & 168.3 & 147.9 & -12.1 & 24.9 & 24.7 & -0.8 & 24.7 & 24.5 & -0.8 \\
\hline $\begin{array}{l}\text { Married to } \\
\text { widowed }\end{array}$ & 208.6 & 196.9 & -5.6 & 220.8 & 163.3 & -26.1 & 54.6 & 60.4 & 10.6 & 121.7 & 76.0 & -37.6 \\
\hline $\begin{array}{c}\text { Married to } \\
\text { married }\end{array}$ & 257.8 & 273.1 & 5.9 & 278.4 & 251.5 & -9.7 & 147.6 & 157.6 & 6.8 & 164.5 & 144.2 & -12.3 \\
\hline \multicolumn{13}{|c|}{ Net financial assets } \\
\hline \multicolumn{13}{|c|}{ Aged $65-74$ in 2005} \\
\hline $\begin{array}{c}\text { Widowed to } \\
\text { widowed }\end{array}$ & 67.4 & 69.1 & 2.5 & 69.4 & 59.8 & -13.8 & 17.6 & 17.9 & 1.7 & 18.0 & 18.1 & 0.6 \\
\hline $\begin{array}{l}\text { Married to } \\
\text { widowed }\end{array}$ & 84.4 & 77.6 & -8.0 & 101.3 & 89.7 & -11.5 & 28.2 & 24.6 & -12.8 & 32.2 & 28.2 & -12.4 \\
\hline $\begin{array}{l}\text { Married to } \\
\text { married }\end{array}$ & 115.8 & 122.6 & 5.9 & 125.0 & 114.1 & -8.7 & 32.4 & 33.9 & 4.6 & 34.6 & 35.4 & 2.3 \\
\hline \multicolumn{13}{|c|}{ Aged $75+$ in 2005} \\
\hline $\begin{array}{c}\text { Widowed to } \\
\text { widowed }\end{array}$ & 79.3 & 76.5 & -3.6 & 77.3 & 70.4 & -9.0 & 21.8 & 22.3 & 2.3 & 22.8 & 22.0 & -3.5 \\
\hline $\begin{array}{l}\text { Married to } \\
\text { widowed }\end{array}$ & 130.5 & 100.5 & -23.0 & 118.6 & 72.4 & -39.0 & 33.4 & 29.5 & -11.7 & 42.4 & 24.5 & -42.2 \\
\hline $\begin{array}{c}\text { Married to } \\
\text { married }\end{array}$ & 120.1 & 126.9 & 5.7 & 130.0 & 125.5 & -3.5 & 42.6 & 45.7 & 7.3 & 45.8 & 45.4 & -0.9 \\
\hline
\end{tabular}

that the children demand their statutory portion (of the estate) if economic prospects are poor, which results in the sale of the house. In addition, we observe a significant reduction in ownership of risky assets among widowed households compared to sur- 
Table 8 continued

\begin{tabular}{|c|c|c|c|c|c|c|c|c|c|c|c|c|}
\hline & \multicolumn{6}{|l|}{ Mean } & \multicolumn{6}{|c|}{ Median } \\
\hline & $t$ & $t+2$ & $\% \Delta$ & $t$ & $t+2$ & $\% \Delta$ & $t$ & $t+2$ & $\% \Delta$ & $t$ & $t+2$ & $\% \Delta$ \\
\hline & 2005 & 2007 & & 2007 & 2009 & & 2005 & 2007 & $\% \Delta$ & 2007 & 2009 & $\% \Delta$ \\
\hline \multicolumn{13}{|l|}{ All } \\
\hline $\begin{array}{c}\text { Widowed to } \\
\text { widowed }\end{array}$ & 74.6 & 73.6 & -1.4 & 74.1 & 66.1 & -10.8 & 20.4 & 20.8 & 2.0 & 21.1 & 20.7 & -1.9 \\
\hline $\begin{array}{l}\text { Married to } \\
\text { widowed }\end{array}$ & 109.3 & 89.9 & -17.7 & 108.5 & 82.5 & -24.0 & 30.0 & 27.1 & -9.7 & 39.4 & 25.4 & -35.5 \\
\hline $\begin{array}{c}\text { Married to } \\
\text { married }\end{array}$ & 117.3 & 124.1 & 5.8 & 126.7 & 117.9 & -6.9 & 35.7 & 37.4 & 4.8 & 38.3 & 38.9 & 1.6 \\
\hline
\end{tabular}

All amounts are expressed in $€ 1000$ and in 2010 prices using the CPI deflator

viving couples (observing not only the ownership rate but also the average portfolio share). In contrast to housing equity, the effect of widowhood on risky assets is much stronger in the years before the financial crisis. These opposite effects of risky assets and housing equity might explain why there is no clear-cut effect of widowhood on the share of savings in checking and savings accounts.

The observation that widowhood is associated with a reduction in the portfolio share and ownership of risky assets is not in line with Coile and Milligan (2009), who find that widowhood increases the share of assets held in liquid financial assets such as stocks and mutual funds (but also checking and savings accounts) and reduces the share of assets held in illiquid assets such as housing. This suggests that widowed persons prefer liquid household portfolios (to pay for health expenditures, for example). Our results indicate that widowed persons prefer less complex and less risky household portfolios. Whether they sell their house or stocks depends on the economic situation. The liquidity consideration might be less relevant in the Netherlands.

\section{Health Status, Wealth Holdings and Financial Portfolios}

We have shown above that widowhood at an early age is associated with lower wealth. In addition, persons with low lifetime income often have little wealth holdings. This suggests that health differences are important in explaining the financial status of the elderly: health problems in working life reduce the ability to work, which leads to lower pensions and less private savings; in retirement, these health problems lead to early death. For example, Smith (2004) shows for US households that the unfolding of a major health event leads to a large cumulative loss in income and consequently less wealth accumulation and reduced pensions.

There are other ways in which health status affects economic resources after retirement. A new health problem might lead to sizable out-of-pocket medical expenses, which reduce savings in case of limited insurance coverage. In addition, health status might affect the level of non-medical consumption. Finally, health shocks might reduce the expected remaining lifetime. This reduces the marginal utility of holding 
Table 9 Marital status transition and changes in household portfolio composition

\begin{tabular}{|c|c|c|c|c|c|c|c|c|c|c|c|c|}
\hline & \multicolumn{6}{|c|}{ Ownership rate $(\%)$} & \multicolumn{6}{|c|}{ Mean portfolio share } \\
\hline & $t$ & $t+2$ & $\% \Delta$ & $t$ & $t+2$ & $\% \Delta$ & $t$ & $t+2$ & $\% \Delta$ & $t$ & $t+2$ & $\% \Delta$ \\
\hline & 2005 & 2007 & & 2007 & 2009 & & 2005 & 2007 & & 2007 & 2009 & \\
\hline \multicolumn{13}{|l|}{ All } \\
\hline \multicolumn{13}{|c|}{ Checking and savings accounts } \\
\hline $\begin{array}{c}\text { Widowed to } \\
\text { widowed }\end{array}$ & 91.1 & 93.6 & 2.7 & 93.3 & 94.5 & 1.4 & 65.1 & 65.9 & 1.2 & 65.5 & 67.2 & 2.7 \\
\hline $\begin{array}{l}\text { Married to } \\
\text { widowed }\end{array}$ & 95.6 & 98.2 & 2.8 & 96.8 & 93.5 & -3.3 & 63.4 & 61.4 & -3.2 & 62.0 & 65.5 & 5.7 \\
\hline $\begin{array}{c}\text { Married to } \\
\text { married }\end{array}$ & 97.6 & 97.4 & -0.1 & 97.9 & 98.2 & 0.3 & 52.2 & 51.7 & -1.0 & 51.1 & 53.7 & 5.2 \\
\hline \multicolumn{13}{|l|}{ Risky assets } \\
\hline $\begin{array}{c}\text { Widowed to } \\
\text { widowed }\end{array}$ & 19.2 & 16.8 & -12.4 & 16.4 & 15.6 & -4.6 & 5.9 & 5.2 & -12.5 & 4.9 & 4.2 & -14.4 \\
\hline $\begin{array}{l}\text { Married to } \\
\text { widowed }\end{array}$ & 17.7 & 11.5 & -35.0 & 19.4 & 16.9 & -12.5 & 3.7 & 2.8 & -25.0 & 2.9 & 2.3 & -21.5 \\
\hline $\begin{array}{c}\text { Married to } \\
\text { married }\end{array}$ & 28.7 & 24.7 & -13.9 & 25.3 & 22.8 & -9.8 & 6.3 & 5.4 & -15.6 & 5.5 & 4.6 & -17.4 \\
\hline \multicolumn{13}{|l|}{ House } \\
\hline $\begin{array}{c}\text { Widowed to } \\
\text { widowed }\end{array}$ & 31.6 & 32.7 & 3.5 & 33.0 & 32.3 & -2.1 & 26.0 & 26.8 & 2.9 & 27.2 & 26.1 & -4.1 \\
\hline $\begin{array}{l}\text { Married to } \\
\text { widowed }\end{array}$ & 37.2 & 38.9 & 4.6 & 42.7 & 36.3 & -15.0 & 28.2 & 30.4 & 8.1 & 32.5 & 28.7 & -11.6 \\
\hline $\begin{array}{c}\text { Married to } \\
\text { married }\end{array}$ & 50.3 & 52.3 & 4.0 & 53.3 & 51.6 & -3.2 & 38.5 & 40.2 & 4.3 & 40.6 & 38.7 & -4.8 \\
\hline \multicolumn{13}{|l|}{ Mortgage debt } \\
\hline $\begin{array}{c}\text { Widowed to } \\
\text { widowed }\end{array}$ & 14.1 & 13.0 & -7.9 & 13.0 & 12.3 & -5.4 & 2.5 & 2.3 & -10.9 & 2.3 & 2.5 & 10.8 \\
\hline $\begin{array}{l}\text { Married to } \\
\text { widowed }\end{array}$ & 17.7 & 16.8 & -5.0 & 20.2 & 17.7 & -12.0 & 2.1 & 2.2 & 3.0 & 3.6 & 4.2 & 16.9 \\
\hline $\begin{array}{c}\text { Married to } \\
\text { married }\end{array}$ & 27.1 & 25.4 & -6.3 & 26.1 & 24.0 & -8.0 & 5.7 & 5.6 & -2.2 & 5.7 & 5.4 & -5.7 \\
\hline
\end{tabular}

'Mean portfolio share (\%)' reports the average portfolio share of each asset (debt) item in 'total assets'. Total assets is the sum of checking and savings accounts, risky assets, the value of the primary residence (house) and other assets

wealth in the absence of a bequest motive. Wealth holdings are not affected through reduced income in retirement, since all retirees have a certain pension income. However, as already indicated, both pension income and wealth holdings might be adversely affected by pre-existing health problems before retirement.

Since the analysis is at the household level, we account for the health status of both partners in a household. Table 10 shows the association between health status and wealth holdings for different combinations of health and different age groups. The table shows that there is a strong association between wealth holdings and health 
Table 10 Household wealth in 2005 by age, marital status and health status

\begin{tabular}{|c|c|c|c|c|c|c|c|c|c|c|}
\hline & \multicolumn{5}{|c|}{ Married } & \multicolumn{5}{|c|}{ Widowed } \\
\hline & $65-69$ & $70-74$ & $75-79$ & $80-84$ & $85+$ & $65-69$ & $70-74$ & $75-79$ & $80-84$ & $85+$ \\
\hline \multicolumn{11}{|l|}{ Mean balance } \\
\hline \multicolumn{11}{|l|}{ Net worth } \\
\hline $\begin{array}{l}\text { No health } \\
\text { problems }\end{array}$ & 265.6 & 251.7 & 237.5 & 303.4 & 332.4 & 224.4 & 166.9 & 152.7 & 179.3 & 146.2 \\
\hline Minor diseases & 262.6 & 272.7 & 255.6 & 222.8 & 192.9 & 133 & 130.9 & 119.2 & 164.5 & 143.5 \\
\hline Major diseases & 276.2 & 190.4 & 210.4 & 231.6 & 225.8 & 98.4 & 118.2 & 152.2 & 141.4 & 233.4 \\
\hline \multicolumn{11}{|l|}{ Net financial assets } \\
\hline $\begin{array}{l}\text { No health } \\
\text { problems }\end{array}$ & 110.2 & 116.8 & 100.2 & 168.3 & 205.2 & 89.3 & 61.5 & 67.8 & 100.4 & 89.5 \\
\hline Minor diseases & 113.1 & 127.6 & 118.8 & 118 & 113.2 & 55.5 & 42 & 57.7 & 88.7 & 94.5 \\
\hline Major diseases & 141 & 71.2 & 102.7 & 107.3 & 145.4 & 45.3 & 37 & 91.9 & 83.9 & 155.3 \\
\hline \multicolumn{11}{|l|}{ Housing equity } \\
\hline $\begin{array}{l}\text { No health } \\
\text { problems }\end{array}$ & 155.4 & 134.9 & 137.3 & 135 & 127.2 & 135.2 & 105.4 & 84.8 & 79 & 56.6 \\
\hline Minor diseases & 149.5 & 145.2 & 136.8 & 104.8 & 79.6 & 77.5 & 88.9 & 61.6 & 75.8 & 49 \\
\hline Major diseases & 135.2 & 119.1 & 107.7 & 124.3 & 80.5 & 53.1 & 81.2 & 60.3 & 57.5 & 78.1 \\
\hline \multicolumn{11}{|c|}{ Median balance/homeownership \% } \\
\hline \multicolumn{11}{|l|}{ Net worth } \\
\hline $\begin{array}{l}\text { No health } \\
\text { problems }\end{array}$ & 175.9 & 146.3 & 143.2 & 101.7 & 122.8 & 133 & 24.9 & 25 & 24.3 & 24.9 \\
\hline Minor diseases & 158.1 & 161.6 & 112.2 & 69.4 & 64.6 & 13.7 & 24.9 & 21.8 & 24.9 & 23 \\
\hline Major diseases & 110 & 71.2 & 54.1 & 89.4 & 46 & 14.5 & 20.7 & 22.1 & 17.2 & 22.4 \\
\hline \multicolumn{11}{|l|}{ Net financial assets } \\
\hline $\begin{array}{l}\text { No health } \\
\text { problems }\end{array}$ & 31.3 & 34.3 & 38.2 & 41.4 & 46 & 22.5 & 17.2 & 22.5 & 21.2 & 24.6 \\
\hline Minor diseases & 29.4 & 34.9 & 38.8 & 43.7 & 46 & 7.1 & 17.2 & 17.2 & 24 & 21.5 \\
\hline Major diseases & 28.6 & 28.9 & 33.4 & 39.7 & 46 & 9.8 & 11.9 & 18.3 & 12.2 & 17.3 \\
\hline \multicolumn{11}{|l|}{ Homeownership } \\
\hline $\begin{array}{l}\text { No health } \\
\text { problems }\end{array}$ & 60.2 & 48.7 & 46.0 & 39.7 & 37.0 & 48.26 & 36.47 & 30.12 & 25.51 & 17.18 \\
\hline Minor diseases & 54.0 & 51.6 & 44.0 & 36.5 & 30.3 & 27.78 & 34.27 & 23.65 & 25.45 & 18.27 \\
\hline Major diseases & 49.3 & 44.6 & 38.2 & 40.3 & 24.6 & 18.42 & 31.40 & 22.52 & 20.18 & 22.08 \\
\hline
\end{tabular}

All amounts are expressed in thousands of euros and in 2010 prices using the CPI deflator

We distinguish between three categories of diseases: major diseases (cancer or cardiovascular diseases), minor diseases (all other diseases) and the remaining "healthy" group with no hospitalization. For married couples we define the household to have a 'minor disease' if neither the key person nor the partner has a 'major disease' but at least of them is admitted to the hospital during the last three waves

for both the median and mean. For example, a couple between the ages of 75 and 79 with no previous health problems has an average net worth of $€ 237,500$, while a couple of which one or both partners has major health problems has a net worth of $€ 210,000$. This difference can mainly be attributed to differences in homeownership 
status between households with a different health status, as reported in the final column. Homeownership among households aged 75-79 with no preexisting health problems is $46.0 \%$, while homeownership among couples with major health problems is $38.2 \%$. The strong association between health and financial resources, among other things, is found by Poterba et al. (2011), among others. Their study also shows that households in good health have rising wealth profiles in retirement, while unhealthy households have a very flat wealth profile.

Next, we examine whether the onset of a new major disease (cancer or cardiovascular disease) affects wealth holdings between two waves. To analyze the effect of a new health event on wealth, we control for initial health status. We compare households who had no health problems (of any household member) between 2003 and 2005 but experienced different health shocks thereafter. We distinguish between five groups (see Fig. 6). The healthy group (dashed line) experienced no health shock (of any member) between 2005 and 2009 and serves as reference group. The other groups experienced a health shock (of at least one member) between 2005 and 2009 that differs in severity: the second group (dotted line) experienced a minor health shock (of at least one member) between 2005 and 2007 and is readmitted to the hospital for a minor condition between 2007 and 2009; the third group (thick line) experienced a minor health shock (of at least one member) between 2005 and 2007 and a severe health shock between 2007 and 2009; the fourth group (thick dashed line) experiences a severe health shock (of at least one member) between 2005 and 2007 and is readmitted to the hospital for a similar severe condition between 2007 and 2009; the final group (thin line) experienced a health shock (of at least one member) between 2005 and 2007 and one of the members dies in 2010 (not necessarily for the same cause).

Figure 6 shows that there are significant differences in the level of net worth, depending on health status: households experiencing a severe health shock are somewhat poorer, compared to households who experienced a minor health shock or no health shock. The slopes of the lines are very similar, which implies that there is no differential effect of health on mean net worth. When we look at homeownership we do not observe a clear effect of health on the change in homeownership status. Health problems might deter individuals from moving, due to the high physical and psychological burden of moving. Older people might already have moved in anticipation of getting health problems in the near future. Since elderly persons do not move house after the onset of a health event, it is relevant to analyze the effect of health on financial assets. For net financial wealth we also observe the initial differences in net financial wealth among different health groups. Notice that the level of net financial wealth eventually diverges in 2009 for all groups (except for the group of whom one of the members dies in 2010). This implies that those groups who experience a severe health shock accumulate relatively more financial wealth than those who stay in good health.

These results do not match the US evidence, as provided by Poterba et al. (2011), that households with health problems accumulate less wealth than healthy households. Possible explanations are the comprehensive health insurance system in the Netherlands and the relatively high replacement rates in the Netherlands, which guarantee a relatively constant standard of living; see, for example, García-Gómez et al. (2013). Another possibility is a decline in the marginal utility of consumption after a health shock, which results in more savings. 
(a)
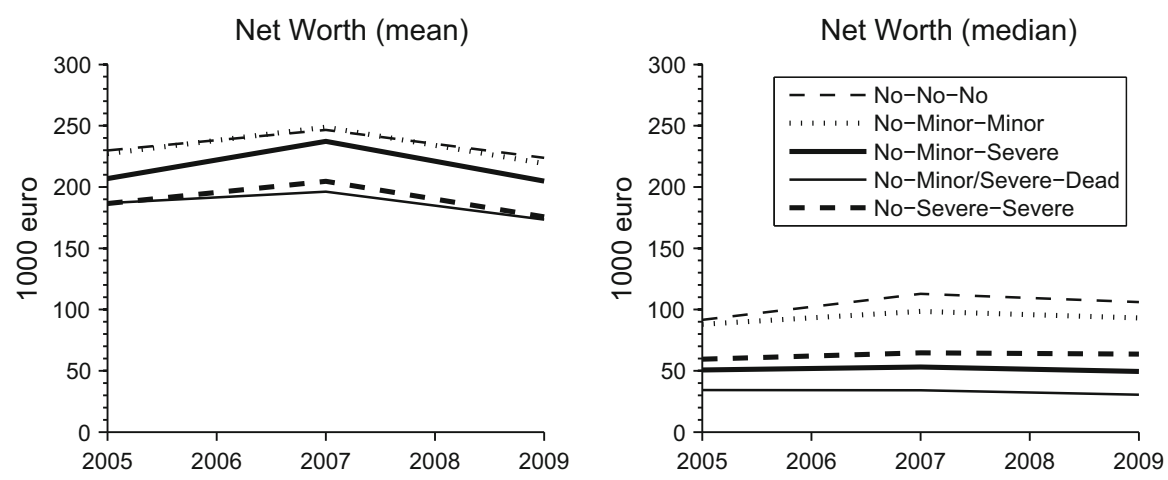

(b)
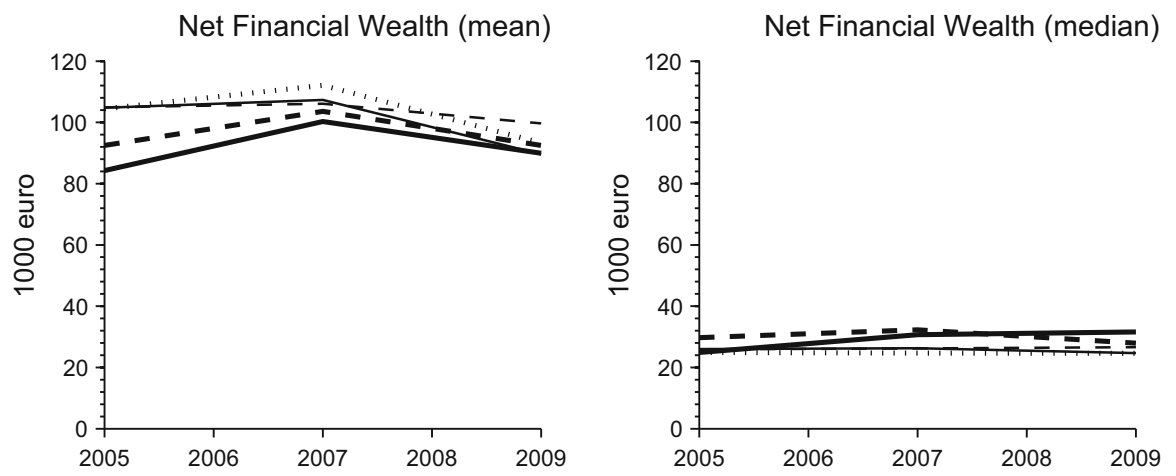

(c)
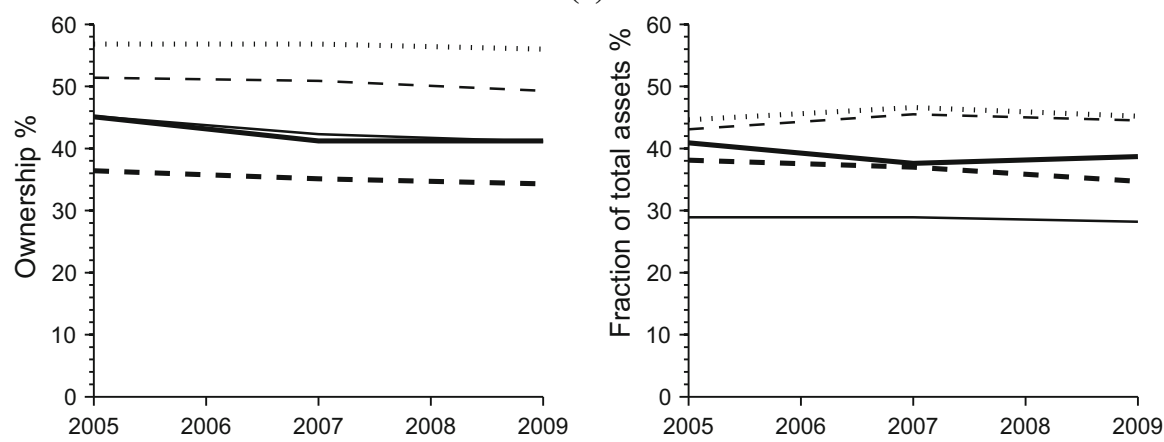

Fig. 6 Health shock and wealth holdings. a Net worth: mean and median, b net financial wealth: mean and median, c primary residence: ownership rate and fraction

\subsection{Household Wealth Before Nursing Home Entry}

Long-term care expenditures account for approximately $25.5 \%$ of health expenditures and $2.9 \%$ of GDP in 2012. These expenditures are almost completely covered by the Exceptional Medical Expenses Act (AWBZ), the public long-term care insurance 
Table 11 Incidence of at least one day of LTC between 2004 and 2011 for the key-person of the household

\begin{tabular}{|c|c|c|c|c|c|c|c|c|}
\hline & \multicolumn{8}{|c|}{ Age group in 2004} \\
\hline & $65-69$ & $70-74$ & $75-79$ & $80-84$ & $85-89$ & $90-94$ & $95+$ & Total \\
\hline Nursing home care & 12.7 & 19.0 & 32.7 & 49.2 & 67.3 & 74.2 & 83.3 & 34.5 \\
\hline $\begin{array}{l}\text { Home care (personal } \\
\text { and nursing) }\end{array}$ & 26.8 & 38.8 & 54.4 & 63.8 & 60.2 & 48.2 & 29.6 & 47.6 \\
\hline Total (No.) & 1816 & 2974 & 2570 & 2088 & 1010 & 461 & 108 & 10,817 \\
\hline
\end{tabular}

Information about long-term care utilization is provided by the CAK 2004-2011

program (CBS, 2012). The projected growth of LTC expenditures puts further pressure on the fiscal budget. As a result, there is growing interest in requiring persons to use their own resources to pay for LTC. LTC services are costly, however, and may require substantial savings.

The most expensive form of LTC is nursing home use. The risk of entering a nursing home is very high: about one-third of the persons over age 65 spent at least one night in a nursing home between 2004 and 2011. The incidence of nursing home entry is particularly high at advanced old age; only one-third of persons aged 85 years and older in 2004 did not stay in a nursing home; see Table 11.

The time that a person spends in a nursing home is distributed very unevenly, which makes total expenditures on LTC uncertain. LTC institutions receive a fixed payment for each patient, depending on the severity of the patient's needs. The payment ranges from $€ 65$ a day for patients with lighter LTC needs, to $€ 270$ a day for patients who are nearing the end of life and have serious LTC needs. A year's stay in a nursing home cost, on average, $€ 58,500$ in $2012^{13}$. This implies that individuals need almost $€ 300,000$ in financial resources to finance a 5-year stay in a nursing home. In particular, with regard to individuals diagnosed with degenerative diseases such as dementia, it is not unlikely that they will spend an enduring period in a nursing home; see e.g. Hurd et al. (2013). In the Netherlands, roughly $30 \%$ of the nursing home population has dementia or related disorders as reported by CIZ in 2012.

Only a small fraction of the elderly would be able to finance nursing home expenditures out-of-pocket using their income and net worth. Table 12 reports the distribution of total resources of single elderly in the year before they permanently enter a nursing home. These resources are in theory available to fund LTC costs. For the vast majority, pension income is well under the amount required to cover these costs. A somewhat larger group would be able to self-support a nursing home stay if they would draw down their private savings. Table 13 shows the maximum number of years of nursing home use that these persons would be able to finance from their private resources; we assume that the costs of LTC move in line with asset prices and that there are no transaction costs involved with selling the house. Only $40 \%$ of nursing home residents would be able to pay out-of-pocket a nursing home stay of more than 1 year; only $20 \%$ of the residents would be able to finance a nursing home stay of more than 5 years. This group consists primarily of homeowners.

$\overline{13}$ Authors' calculations using information taken from the NZA and CIZ. 
Table 12 Total resources of single elderly in the year before they permanently enter a nursing home (2005-2009) (\%)

\begin{tabular}{lllll}
\hline Net worth (in € 1000s) & \multicolumn{4}{l}{ Net income (in € 1000s) } \\
\cline { 2 - 5 } & $<15$ & $15-25$ & $25+$ & Total (No.) \\
\hline$<25$ & 72.3 & 61.0 & 13.6 & 501 \\
Net worth 26-50 & 6.6 & 10.1 & 9.5 & 79 \\
Net worth 51-100 & 5.8 & 6.7 & 7.5 & 58 \\
Net worth 101-200 & 7.3 & 5.4 & 10.9 & 61 \\
Net worth 201-300 & 4.4 & 7.3 & 14.3 & 67 \\
Net worth 300+ & 3.6 & 9.5 & 44.2 & 119 \\
Total (No.) & 274 & 464 & 147 & 885 \\
\hline
\end{tabular}

Table 13 Years of nursing home stay covered by private resources (\%)

\begin{tabular}{lccccccr}
\hline & $<1$ year & $1-2$ & $2-3$ & $3-4$ & $4-5$ & $>5$ years & Total \\
\hline Renters & 61.7 & 7.1 & 3.7 & 1.0 & 1.2 & 4.4 & 79.2 \\
Homeowners & 0.8 & 0.0 & 0.6 & 0.8 & 1.9 & 16.7 & 20.8 \\
Total & 62.5 & 7.1 & 4.3 & 1.8 & 3.2 & 21.1 & 100.0 \\
\hline
\end{tabular}

The table shows the maximum number of years of nursing home use that single elderly would be able to finance from private resources. The resources are measured in the year before entering a nursing home and include both income and net worth

This calculation does not even take into account the possible use of home care services prior to entering a nursing home. Although the cost of receiving nursing care or personal care at home is somewhat less expensive, the likelihood of receiving home care is very high; see Table 11.

\section{Savings During the Last Years of Life}

We find that the elderly, on average, keep large amounts of assets even at a very old age and do not decumulate assets. In the absence of a bequest motive, they might hold these assets because of uncertainty about the time of death or uncertain expenses in the last years of life. In that case, we should find that households start drawing down their money in the last phase of life and this holds in particular for individuals in poor health who have a lower life expectancy.

Table 14 reports wealth levels in the first wave (2005) and final wave (2010) for single households with no pre-existing health problems. The first set of columns of the table shows the trajectory of wealth holdings for individuals who do not die between 2005 and 2011. The second set of columns shows the trajectory of wealth for individuals who die between 2005 and 2011. These columns indicate that assets decline in the reporting period. However, there is no difference in the decline between both groups. The table also shows the same analysis for single households with major pre-existing health problems before 2005. The table indicates that there is differential mortality between both groups. There is no evidence of dissaving in the years before death. 
Table 14 Net worth before death (1000 euro), single households, age 70 and older in 2005

\begin{tabular}{|c|c|c|c|c|c|c|}
\hline & \multicolumn{3}{|c|}{ Survives } & \multicolumn{3}{|l|}{ Dies } \\
\hline & 2005 & $\Delta$ annual & $\Delta$ final year & 2005 & $\Delta$ annual & $\Delta$ final year \\
\hline \multicolumn{7}{|c|}{ No health problems } \\
\hline Mean & 187.5 & -2.85 & -6.1 & 185.5 & -1.62 & -5.89 \\
\hline Median & 24.85 & -0.02 & -0.2 & 24.85 & 0.02 & -0.08 \\
\hline Obs & 997 & & & 437 & & \\
\hline \multicolumn{7}{|c|}{ Minor health problems } \\
\hline Mean & 158.3 & -2.13 & -3.17 & 140.9 & 1.3 & -5.08 \\
\hline Median & 24.85 & -0.02 & -0.2 & 22.7 & 0 & 0 \\
\hline Obs & 587 & & & 364 & & \\
\hline \multicolumn{7}{|c|}{ Major health problems } \\
\hline Mean & 159.7 & -4.27 & -4.68 & 149.1 & -3.58 & -4.7 \\
\hline Median & 24.85 & 0 & -0.2 & 20.9 & 0.04 & 0.01 \\
\hline Obs & 526 & & & 415 & & \\
\hline
\end{tabular}

All amounts are expressed in thousands of euros and in 2010 prices using the CPI deflator

We distinguish between three categories of diseases: major diseases (cancer or cardiovascular diseases), minor diseases (all other diseases) and the remaining "healthy" group with no hospitalization. For married couples we define the household to have a 'minor disease' if neither the key person nor the partner has a 'major disease' but at least of them is admitted to the hospital during the last three waves

It seems that individuals in poor health save during the last years of life. These results are not in line with evidence from US studies, which find a large decline in assets in late-life (e.g. French et al. 2006). Poterba et al. (2014) show that the decline in assets at the end of life is strongly associated with deteriorating health and not caused by an underestimation of life expectancy or lower pension benefits. This suggests that medical expenditure risk is not important in the Netherlands and that a bequest motive might be relevant.

\section{Conclusion}

The elderly, on average, keep large amounts of assets even at a very old age, and they leave a considerable bequest. We do not find evidence of decumulation of wealth after retirement for singles, despite the fact that retirees face limited income uncertainty and limited uncertainty about out-of-pocket payments for medical expenses. We find some suggestive evidence of dissaving for high-income widowed persons.

At the median, we observe that the elderly have accumulated a decent buffer of financial wealth, high enough to cover small unexpected expenses but too small to significantly increase consumption in retirement. These households depend mainly on social security and pension income to support retirement consumption.

Our results also show that not many homeowners sell off their house to finance their retirement, and it is very likely that homeownership among the elderly will increase in the future because of cohort effects. There is some suggestive evidence that younger elderly persons extract housing equity by means of interest-only mortgages. 
There are large initial differences in the level of wealth holdings among different health groups and between couples and singles. The latter is most likely related to the socioeconomic status of households, since we do not find major differences in the decumulation pattern for different health groups. The onset of a newly diagnosed severe health condition even results in increased savings in financial assets. A possible explanation for this finding is that deteriorating health constrains non-health-care consumption. Persons in bad health are no longer able to travel or to enjoy leisure activities and they consume less food. It is questionable whether people take this declining consumption path into account when planning for retirement. This results in higher savings in old-age.

The bereavement of a spouse results in a significant reduction of net worth compared to surviving couples, in both the period before and after the financial crisis. We also observe a slight reduction in homeownership after the death of a spouse (in the years after the financial crisis) and a significant reduction in the ownership rate and portfolio share of risky assets (in the years before the financial crisis). The reduction in homeownership indicates that people downsize their housing wealth when they become widowed. The collected assets from the sale of the house might partly be transferred to the heirs, resulting in a drop in net worth. Not surprisingly, we find strong evidence of differential mortality, which also explains the differences in household portfolios between widowed persons and married couples.

It can be concluded that a simple life-cycle model is soundly rejected. To explain the saving behavior of the elderly, it is important to consider extended versions of this basic model that explicitly take into account not only a bequest motive, but also the role of lifetime uncertainty, housing, family structures and (wealth and estate) tax-rules. In addition, it is important to allow for health-dependent utility. It is unclear whether the observed large bequests are intended or accidental. Data on the economic status of the children and the exact division of the estate among the heirs might allow us to approach this important research question in future research.

These results are relevant for public policies that seek to encourage the use of private savings to cover risks in retirement, such as out-of-pocket LTC expenses, and to support consumption in retirement. We briefly discuss policy measures which stem from the analysis below.

\subsection{Facilitate the Use of Housing Assets for Long-Term Care}

Housing equity is rarely spent throughout old-age and is commonly left as a bequest. Housing equity is a very suitable means to save for LTC because the elderly do not downsize their housing equity except in the event of severe illness or after the decease of the spouse. This implies that housing equity becomes available in situations when health and LTC expenditures are potentially large. We show that for the vast majority of homeowners who permanently enter a nursing home, the proceeds from the sale of the house can cover a nursing-home stay of more than 5 years. Housing equity is therefore a valuable vehicle to save for LTC services that will not be covered by the public LTC insurance system, such as a stay in a nursing home with better care facilities. 
The government can encourage the accumulation of housing equity by allowing individuals to use part of their pension savings to pay off mortgage debt or by discouraging home equity borrowing before retirement. A lower mortgage debt also reduces the costs of living because of lower mortgage payments. This provides more scope to cover immediate costs from financial assets without the need to sell the house. In addition, the government should discourage transfers to the children after the decease of the spouse. Our analysis suggests that these transfers are currently substantial.

Housing equity is essentially not available for LTC expenses unless a person sells the house and moves elsewhere. Financial products to extract home equity such as reverse mortgages are therefore beneficial if a person desires care at home or if only one of the household members moves to a nursing home. The market for these type of products is thin, partly because of the relative high costs of compensating the lender for the large risk that the total amount of monthly payments exceeds the value of the house. This is either because the last surviving borrower remains in the home for a long period or because house prices decline.

A reverse mortgage product providing a line of credit that can only be used for LTC expenses reduces this risk, for two reasons. First, persons in need of LTC are already at an advanced age and typically remain in their home for a relatively short period. Second, given that the line of credit can only be used for LTC-related expenses, there is a lower risk that all home equity will be spent. This is also beneficial for people who like to leave a bequest.

\subsection{Eligibility for Public Long-Term Care Insurance Should Not Depend on Wealth Holdings}

People who find it important to save for LTC are discouraged doing so if the eligibility for public LTC depends on the level of wealth. There is strong empirical evidence that the introduction of asset-testing — which requires persons to first run down their assets in order to become eligible for public LTC_-discourages saving, particularly if the quality of publicly provided LTC is high. For the Netherlands, anecdotal evidence suggests that the recent introduction of a wealth-based payment for nursing-home care led to increased transfers of wealth between parents and children.

A means-tested system that is based only on the level of income does not have these disadvantages. To restrict the utilization of public-provided care it is therefore more efficient to increase income-related payments. A benchmark study about LTC expenses among OECD countries shows that income-related payments are relatively low in the Netherlands (OECD 2011). This holds in particular for care at home. When an individual is unable to pay these higher income-related expenses, they can be deferred until after death. At that time, claims can be recovered from the estate before the estate is transferred to the heirs.

\subsection{Align Pension Benefits with Consumption Needs in Old-Age}

In the current pension system, pension income does not decrease with age. This does not reflect the declining needs as people age. Our analysis provides evidence that the 
marginal utility of consumption declines in old-age because of deteriorating health. This results in higher savings in old-age due to the comprehensive coverage of health care expenditures. It is questionable whether people take this declining consumption path into account while planning for retirement. Besides, they are not able to borrow against future pension benefits to increase consumption at the start of retirement. To align pension benefits with actual consumption needs, we propose a pension payout that declines with age.

The available funds can, if desired, be provided for LTC services that will not be covered by the public LTC insurance system, such as a stay in a nursing home with better care facilities or more intensive home care that makes it possible to stay at home for a longer period.

\subsection{Integrate Pensions and Long-Term Care}

Our analysis shows that a sizable fraction of the Dutch elderly has accumulated a small buffer of financial wealth that is sufficient for small incidental expenditures but insufficient for large expenditures such as LTC. This predominantly holds for renters. The introduction of individual saving accounts for LTC is inefficient, since they demand excessive wealth accumulation to self-insure against potentially large LTC expenses. Moreover, it is doubtful whether these accounts generate additional savings by people with a low income who have little room for saving.

One attractive alternative is to require persons at retirement to make an active choice between a lower (age-declining) pension (which provides additional payments when persons are in need of LTC) and a 'normal' pension (which provides a constant stream of pension benefits). The exact additional payments will depend on the severity of the disability, which is determined by an assessment of needs. The problem of adverse selection in this product is limited, for two reasons. First of all, persons who are in need of LTC have a lower life expectancy and consequently a lower expected present discounted value of future pension benefits. Second, persons have to commit themselves for one of both products already at the start of retirement when the prevalence of LTC is low. Asymmetric information about future LTC use is also limited at an earlier age. An additional benefit of combining LTC and pensions is that it leads to a reduction in costs. ${ }^{14}$

Another possibility is to use these funds to pay for the premiums of an LTC policy, which covers the costs of LTC on top of the basic public LTC. The experience from different countries, such as the US and the UK, shows that the willingness to buy these insurance products is very low. We will therefore not consider the possibility of private LTC insurance as a supplement to publicly provided LTC.

\footnotetext{
Open Access This article is distributed under the terms of the Creative Commons Attribution 4.0 International License (http://creativecommons.org/licenses/by/4.0/), which permits unrestricted use, distribution, and reproduction in any medium, provided you give appropriate credit to the original author(s) and the source, provide a link to the Creative Commons license, and indicate if changes were made.
}

14 See also Murtaugh et al. (2001) for an extensive welfare analysis of a combination of LTC and annuities. 


\section{References}

Alessie, R., Hoghguertel, S., \& Van Soest, A. (2002). Household portfolios in the Netherlands. In L. Guiso, M. Haliassos, \& T. Jappelli (Eds.), Household portfolios (pp. 341-388). Cambridge: MIT Press.

Alessie, R., Kapteyn, A., \& Klijn, F. (1997). Mandatory pensions and personal savings in the Netherlands. De Economist, 145(3), 291-324.

Alessie, R., Lusardi, A., \& Kapteyn, A. (1995). Saving and wealth holdings of the elderly. Ricerche Economiche, 49(3), 293-314.

Alessie, R., Lusardi, A., \& Kapteyn, A. (1999). Saving after retirement: Evidence based on three different savings measures. Labour Economics, 6(2), 277-310.

Ameriks, J., Caplin, A., Laufer, S., \& Van Nieuwerburgh, S. (2011). The joy of giving or assisted living? Using strategic surveys to separate public care aversion from bequest motives. The Journal of Finance, 66(2), 519-561.

Ando, A., \& Guiso, L. (1994). Dissaving by the elderly, transfer motives and liquidity constraints. In A. Ando \& L. Guiso (Eds.), Saving and the accumulation of wealth: Essays on Italian household and government saving behavior (pp. 188-213). Cambridge: Cambridge University Press.

Attanasio, O., \& Hoynes, H. W. (2000). Differential mortality and wealth accumulation. Journal of Human Resources, 35(1), 1-29.

Becker, G., \& Tomes, N. (1979). An equilibrium theory of the distribution of income and intergenerational mobility. The Journal of Political Economy, 87(6), 1153-1189.

Benartzi, S., Previtero, A., \& Thaler, R. (2011). Annuitization puzzles. The Journal of Economic Perspectives, 25(4), 143-164.

Berkowitz, M., \& Qiu, J. (2006). A further look at household portfolio choice and health status. Journal of Banking and Finance, 30(4), 1201-1217.

Börsch-Supan, A. (1992). Saving and consumption patterns of the elderly: The German case. Journal of Population Economics, 5(4), 289-303.

Börsch-Supan, A., \& Stahl, K. (1991). Life cycle savings and consumption constraints. Journal of Population Economics, 4(3), 233-255.

Bovenberg, A. L., \& Gradus, R. (2008). Dutch policies towards ageing. European View, 23, 265-275.

Bridges, S., Disney, R., \& Henley, A. (2006). Housing wealth and the accumulation of financial debt: Evidence from UK households. In C. G. Giuseppe Bertola \& R. Disney (Eds.), The economics of consumer credit (pp. 135-180). Cambridge: MIT Press.

Brown, J., \& Nijman, T. (2011). Opportunities for improving pension wealth decumulation in the Netherlands. Discussion paper, Netspar.

Browning, M. (2000). The saving behaviour of a two-person household. The Scandinavian Journal of Economics, 102(2), 235-251.

Card, D., Chetty, R., Feldstein, M., \& Saez, E. (2010). Expanding access to administrative data for research in the United States. White paper, National Science Foundation.

Carroll, C. (2000). Why do the rich save so much? Does atlas shrug?: The economic consequences of taxing the rich, p. 465.

Carroll, C. (2001). A theory of the consumption function, with and without liquidity constraints. The Journal of Economic Perspectives, 15(3), 23-45.

Chetty, R., \& Szeidl, A. (2007). Consumption commitments and risk preferences. The Quarterly Journal of Economics, 122(2), 831-877.

Chetty, R. \& Szeidl, A. (2010). The effect of housing on portfolio choice. NBER Working Paper 15998, National Bureau of Economic Research.

Coile, C., \& Milligan, K. (2009). How household portfolios evolve after retirement: The effect of aging and health shocks. Review of Income and Wealth, 55(2), 226-248.

Datta Gupta, N., Kleinjans, K. \& Larsen, M. (2011). The effect of an acute health shock on work behavior: Evidence from different health care regimes. IZA Discussion Papers 5843, Institute for the Study of Labor.

Davidoff, T. (2010). Home equity commitment and long-term care insurance demand. Journal of Public Economics, 94(1), 44-49.

Davies, J. (1981). Uncertain lifetime, consumption, and dissaving in retirement. Journal of Political Economy, 89(3), 561-577.

De Nardi, M. (2004). Wealth inequality and intergenerational links. Review of Economic Studies, 3(71), $743-768$. 
De Nardi, M., French, E., \& Jones, J. (2010). Why do the elderly save? The role of medical expenses. Journal of Political Economy, 118(1), 39-75.

Deaton, A., \& Paxson, C. (1994). Intertemporal choice and inequality. Journal of Political Economy, 102(3), 437-467.

Diamond, P., \& Hausman, J. (1984). Individual retirement and savings behavior. Journal of Public Economics, 23(1-2), 81-114.

Dynan, K., Mian, A., \& Pence, K. (2012). Is a household debt overhang holding back consumption? Brookings Papers on Economic Activity, 44(1), 299-362.

Dynan, K., Skinner, J., \& Zeldes, S. (2002). The importance of bequests and life-cycle saving in capital accumulation: A new answer. The American Economic Review, 92(2), 274-278.

Dynan, K., Skinner, J., \& Zeldes, S. (2004). Do the rich save more? The Journal of Political Economy, 112(2), 397-444.

Feenberg, D., \& Skinner, J. (1994). The risk and duration of catastrophic health care expenditures. The Review of Economics and Statistics, 76(4), 633-647.

Feinstein, J., \& McFadden, D. (1989). The dynamics of housing demand by the elderly: Wealth, cash flow, and demographic effects. In D. Wise (Ed.), The economics of aging (pp. 55-92). Chicago: University of Chicago Press.

Finkelstein, A., Luttmer, E., \& Notowidigdo, M. (2013). What good is wealth without health? The effect of health on the marginal utility of consumption. Journal of the European Economic Association, 11(1), 221-258.

Flavin, M., \& Yamashita, T. (2002). Owner-occupied housing and the composition of the household portfolio. The American Economic Review, 92(1), 345-362.

Frederick, S., Loewenstein, G., \& O’Donoghue, T. (2002). Time discounting and time preference: A critical review. Journal of Economic Literature, 40(2), 351-401.

French, E., De Nardi, M., Jones, J., Baker, O. \& Doctor, P. (2006). Right before the end: Asset decumulation at the end of life. Economic Perspectives, Federal Reserve Bank of Chicago 3rd Quarter, 2-13.

French, E., Doctor, P., \& Baker, O. (2007). Asset rundown after retirement: The importance of rate of return shocks. Economic Perspectives, Federal Reserve Bank of Chicago 3rd Quarter, 49-65.

French, E., \& Jones, J. (2004). On the distribution and dynamics of health care costs. Journal of Applied Econometrics, 19(6), 705-721.

García-Gómez, P., Van Kippersluis, H., O’Donnell, O., \& Van Doorslaer, E. (2013). Long-term and spillover effects of health shocks on employment and income. Journal of Human Resources, 48(4), 873-909.

Gollier, C. (2002). What does theory have to say about household portfolios? In L. Guiso, M. Haliassos, \& T. Jappelli (Eds.), Household portfolios (pp. 27-54). Cambridge: MIT Press.

Henderson, J., \& Ioannides, Y. (1983). A model of housing tenure choice. The American Economic Review, $73(1), 98-113$.

Hubbard, R. G., Skinner, J., \& Zeldes, S. (1995). Precautionary saving and social insurance. Journal of Political Economy, 103(2), 360-399.

Hurd, M. (1987). Savings of the elderly and desired bequests. The American Economic Review, 77(3), $298-312$.

Hurd, M. (1989). Mortality risk and bequests. Econometrica, 57(4), 779-813.

Hurd, M. (1999). Mortality risk and consumption by couples. NBER Working Paper 7048, National Bureau of Economic Research.

Hurd, M. (2002). Portfolio holdings of the elderly. In L. Guiso, M. Haliassos, \& T. Jappelli (Eds.), Household portfolios (pp. 341-388). Cambridge: MIT Press.

Hurd, M., Martorell, P., Delavande, A., Mullen, K., \& Langa, K. (2013). Monetary costs of dementia in the United States. New England Journal of Medicine, 368(14), 1326-1334.

Hurd, M., \& Smith, J. (2001). Anticipated and actual bequests. In D. A. Wise (Ed.), Themes in the economics of aging (pp. 357-392). Chicago: University of Chicago Press.

Kalwij, A., Alessie, R., \& Knoef, M. (2013). The association between individual income and remaining life expectancy at the age of 65 in the Netherlands. Demography, 50(1), 181-206.

Kapteyn, A., Alessie, R., \& Lusardi, A. (2005). Explaining the wealth holdings of different cohorts: Productivity growth and social security. European Economic Review, 49(5), 1361-1391.

Kopczuk, W., \& Lupton, J. (2007). To leave or not to leave: The distribution of bequest motives. The Review of Economic Studies, 74(1), 207-235.

Kotlikoff, L. (1989). Health expenditures and precautionary savings. In What determines savings?, Vol. 1. MIT Press. 
Laitner, J., \& Juster, F. T. (1996). New evidence on altruism: A study of TIAA-CREF retirees. The American Economic Review, 86(4), 893-908.

Lillard, L., \& Weiss, Y. (1997). Uncertain health and survival: Effects on end-of-life consumption. Journal of Business \& Economic Statistics, 15(2), 254-268.

Lockwood, L. (2012). Bequest motives and the annuity puzzle. Review of Economic Dynamics, 15(2), 226-243.

Love, D., Palumbo, M., \& Smith, P. (2009). The trajectory of wealth in retirement. Journal of Public Economics, 93(1-2), 191-208.

Mariger, R. (1987). A life-cycle consumption model with liquidity constraints: Theory and empirical results. Econometrica, 55(3), 533-557.

McGarry, K. (1999). Inter vivos transfers and intended bequests. Journal of Public Economics, 73(3), 321-351.

Modigliani, F., \& Brumberg, R. (1954). Utility analysis and the consumption function: An interpretation of the cross-section data. In K. Kurihara (Ed.), Post-Keynesian economics (pp. 388-436). New Brunswick: Rutgers University Press.

Murtaugh, C., Spillman, B., \& Warshawsky, M. (2001). In sickness and in health: An annuity approach to financing long-term care and retirement income. Journal of Risk and Insurance, 68(2), 225-253.

OECD. (2011). Help wanted? Providing and paying for long-term care. Health policy studies, OECD.

Palumbo, M. (1999). Uncertain medical expenses and precautionary saving near the end of the life cycle. The Review of Economic Studies, 66(2), 395-421.

Pelizzon, L., \& Weber, G. (2009). Efficient portfolios when housing needs change over the life cycle. Journal of Banking \& Finance, 33(11), 2110-2121.

Poterba, J., Venti, S., \& Wise, D. (2011). Family status transitions, latent health, and the post-retirement evolution of assets. In D. Wise (Ed.), Explorations in the economics of aging (pp. 23-69). Chicago: University of Chicago Press.

Poterba, J., Venti, S., \& Wise, D. (2012). Were they prepared for retirement? Financial status at advanced ages in the HRS and the AHEAD cohorts. In D. Wise (Ed.), Investigations in the economics of aging (pp. 21-69). Chicago: University of Chicago Press.

Poterba, J., Venti, S., \& Wise, D. (2014). The nexus of social security benefits, health, and wealth at death. In D. Wise (Ed.), Discoveries in the economics of aging (pp. 159-186). Chicago: University of Chicago Press.

Rouwendal, J., \& Thomese, F. (2013). Homeownership and long-term care. Housing Studies, 28(5), 746763.

Sheiner, L. \& Weil, D. (1992). The housing wealth of the aged. NBER Working Paper 4115, National Bureau of Economic Research.

Shorrocks, A. (1975). The age-wealth relationship: A cross-section and cohort analysis. The Review of Economics and Statistics, 57(2), 155-163.

Sinai, T., \& Souleles, N. (2005). Owner-occupied housing as a hedge against rent risk. The Quarterly Journal of Economics, 120(2), 763-789.

Sinai, T., \& Souleles, N. (2008). Net worth and housing equity in retirement. In J. Ameriks \& O. Mitchell (Eds.), Recalibrating retirement spending and saving. Oxford: Oxford University Press.

Smith, J. (2004). Unraveling the SES: Health connection. Population and Development Review, 30, 108132.

Soede, A. (2012). Tevreden met pensioen. Veranderende inkomens en behoeften bij ouderen. $\mathrm{Ph}$. D. thesis, Sociaal en Cultureel Planbureau, Den Haag.

Thaler, R., \& Shefrin, H. (1981). An economic theory of self-control. The Journal of Political Economy, 89(2), 392-406.

Van Der Schors, A., Alessie, R., \& Mastrogiacomo, M. (2007). Home and mortgage ownership of the Dutch elderly: Explaining cohort, time and age effects. De Economist, 155(1), 99-121.

Van Ooijen, R. \& Van Rooij, M. (2014). Financial literacy, financial advice and mortgage risks. DNB Working Paper, De Nederlandsche Bank (DNB).

Van Ooijen, R., Mastrogiacomo, M., Euwals, R. (2010). Private wealth and planned early retirement: A panel data analysis for the Netherlands. Discussion Paper 160, CPB Netherlands Bureau for Economic Policy Analysis.

Van Rooij, M., Lusardi, A., \& Alessie, R. (2011). Financial literacy and stock market participation. Journal of Financial Economics, 101(2), 449-472. 
Venti, S. \& Wise, D. (2000). Aging and housing equity. Working Paper 7882, National Bureau of Economic Research.

Venti, S. (2011). Economic measurement in the health and retirement study. Forum for Health Economics \& Policy, 14(3), 1-18.

Wolff, E. (1998). Recent trends in the size distribution of household wealth. Journal of Economic Perspectives, 12(3), 131-150.

Yaari, M. (1965). Uncertain lifetime, life insurance, and the theory of the consumer. The Review of Economic Studies, 32(2), 137-150.

Yogo, M. (2009). Portfolio choice in retirement: Health risk and the demand for annuities, housing, and risky assets. NBER Working Paper 15307, National Bureau of Economic Research. 